\title{
Perbuatan Tercela Sebagai Salah Satu Alasan Pemakzulan Presiden Dan/Atau Wakil Presiden Dalam Kajian Hukum Pidana Di Indonesia
}

\author{
Muhammad Irham $^{1 *}$, Nani Mulyati ${ }^{2}$ \\ 1, Fakultas Hukum Universitas Pattimura, Ambon, Indonesia \\ 2, Fakultas Hukum Universitas Andalas, Padang, Indonesia \\ *E-mail:irhamhukum@gmail.com
}

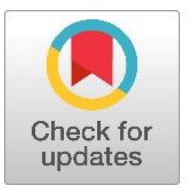

\begin{tabular}{|c|c|}
\hline Dikirim: 30/07/2021 & Dipublikasi: 07/10/2021 \\
\hline Info Artikel & Abstract \\
\hline $\begin{array}{l}\text { Keywords: } \\
\text { Disgraceful Acts; } \\
\text { Impeachment of the } \\
\text { President/Vice } \\
\text { President; Criminal } \\
\text { Law. }\end{array}$ & $\begin{array}{l}\text { The purpose of this study is to find out what is meant by the President and/or } \\
\text { Vice President committing a disgraceful act in the concept of criminal law, } \\
\text { so that they can be impeached. By using normative legal research and } \\
\text { approaches to legal concepts, laws and their history. The results of the } \\
\text { research are as follows: First, all actions that are contrary to the Criminal } \\
\text { Code are disgraceful acts for the President/Vice President; Second, the } \\
\text { religious values, social culture of the Indonesian nation, as well as moral } \\
\text { principles in the Criminal Code have been compiled in Pancasila and the } \\
1945 \text { Constitution, therefore any deviation from the behavior of the } \\
\text { President/Vice President against the } 1945 \text { Constitution is a despicable act; } \\
\text { Third, all disgraceful acts of the President/Vice President that violate } \\
\text { criminal law offenses are subject to criminal sanctions in accordance with } \\
\text { the Criminal Code, so that disgraceful acts that have been formally } \\
\text { regulated in the Criminal Code are not the meaning of disgraceful acts as } \\
\text { referred to in Article } 7 A \text { of the 1945 Constitution, because the limitations } \\
\text { of criminal acts have been determined can impeach the President/Vice } \\
\text { President, namely: corruption, bribery, and other serious crimes; Fourth, } \\
\text { the disgraceful act of the President/Vice President in Article } 7 \text { of the 1945 } \\
\text { Constitution is an act of violating the } 1945 \text { Constitution as a reference to } \\
\text { the rules of criminal law. }\end{array}$ \\
\hline
\end{tabular}

Kata Kunci:

Perbuatan Tercela;

Pemakzulan

Presiden/Wakil

Presiden; Hukum

Pidana.

\begin{abstract}
Abstrak
Tujuan penelitian ini adalah untuk mengetahuan apakah yang dimaksud dengan Presiden dan/atau Wakil Presiden melakukan perbuatan tercela dalam konsep hukum pidana, sehingga dapat dimakzulkan. Dengan menggunakan penelitian hukum normatif dan pendekatan konsep hukum, undang-undang serta sejarahnya. Didapatkan hasil penelitian sebagai berikut: Pertama, semua perbuatan yang bertentangan dengan KUHPidana adalah perbuatan tercela bagi Presiden/Wakil Presiden; Kedua, nilai-nilai agama, sosial budaya bangsa Indoneisa, serta kaedah-kaedah kesusilaan dalam KUHPidana sudah terhimpun dalam Pancasila dan UUD 1945, oleh karenanya penyimpangan perilaku Presiden/Wakil Presiden terhadap UUD 1945 adalah perbuatan tercela; Ketiga, semua perbuatan tercela Presiden/Wakil Presiden yang melanggar delik hukum pidana mendapatkan $\underline{\text { sanksi pidana sesuai dengan KUHPidana, sehingga perbuatan tercela yang }}$
\end{abstract}




\section{DOI:}

10.47268/sasi.v27i3.596

sudah diatur secara formal dalam KUHPidana bukanlah makna perbuatan tercela yang dimaksud dalam Pasal 7A UUD 1945, sebab sudah ditentukan limitatif perbuatan pidana yang dapat memakzulkan Presiden/Wakil Presiden, yakni: korupsi, penyuapan, dan tindak pidana berat lainnya; Keempat, perbuatan tercela Presiden/Wakil Presiden dalam Pasal 7A UUD 1945 adalah perbuatan pelanggaran terhadap UUD 1945 sebagai rujukan kaedah hukum pidana.

\section{A. PENDAHULUAN}

Kajian tentang perbuatan tercela sebagai salah satu alasan pemberhentian Presiden dan/atau Wakil Presiden dalam masa jabatannya (pemakzulan) ini sangat penting dan menarik untuk dilakukan, topik ini menjadi penting sebab rumusan perbuatan tercela dalam Pasal 7A Undang-Undang Dasar 1945 (UUD 1945) tersebut masih abu-abu dan tidak jelas ukuran untuk menilai ketercelaan suatu perbuatan Presiden dan/atau Wakil Presiden. ${ }^{1}$ Menjadi menarik karena dalam konsep hukum pidana, pasti semua tindak pidana adalah merupakan perbuatan tercela, namun tidak semua perbuatan tercela merupakan tindak pidana. ${ }^{2}$

Di Indonesia subtansi hukum pidana ${ }^{3}$ dapat ditemukan dalam Kitab Undang-Undang Hukum Pidana (KUHPidana). ${ }^{4}$ Asas yang paling penting dalam KUHPidana ini adalah asas legalitas, yang bermakna bahwa: "moniat lex, priusquam feriat," artinya undang-undang harus memberikan peringatan terlebih dahulu sebelum merealisasikan ancaman yang terkandung di dalamnya. ${ }^{5}$ Montesquieu menjelaskan, dalam asas legalitas tidak ada yang adil atau yang tidak adil, kecuali telah diperintahakan atau dilarang oleh hukum positif. ${ }^{6}$ Rousseau kemudian memasukan asas tersebut kedalam bentuk konstitusi (UUD 1945), yang berisi bahwa tidak sesuatu yang boleh dipidana, selain karena suatu wet yang ditetapkan dalam undang-undang secara sah. ${ }^{7}$

Asas legalitas sangat penting dan sentral dalam hukum pidana di Indonesia, sebab itu diatur dalam KUHPidana, asas legalitas ini berasal dari doktrin nullum delictum nulla poena sine praevia lege poenali (tiada tindak pidana dan tiada pidana tanpa sebelumnya ditetapkan

1 Norma Pasal 7A UUD 1945, sebagai berikut: "Presiden dan/atau Wakil Presiden dapat diberhentikan dalam masa jabatannya oleh Majelis Permusyawaratan Rakyat atas usul Dewan Perwakilan Rakyat, baik apabila terbukti telah melakukan pelanggaran hukum berupa penghianatan terhadap negara, korupsi, penyuapan dan tindak pidana berat lainnya, atau perbuatan tercela maupun apabila terbukti tidak lagi memenuhi syarat sebagai Presiden dan/atau Wakil Presdien.”

2 Penjelasan ini didapat dari Schaffmeister, Keijzer, dan Sutorius. Baca lebih lanjut buku Sofyan, A., \& Azisa, N. (2016). Hukum Pidana. Cetakan Kesatu. Jakarta: Pustaka Pena Press, h. 99-102.

3 Hukum pidana formil di Indonesia telah diatur dalam Undang-Undang Republik Indonesia Nomor 8 Tahun 1981 (UU No. 8 Tahun 1981) tentang Hukum Acara Pidana, (KUHAP), keberadaan KUHAP ini tentu saja untuk mengapai cita cita bangsa Indonesia sebagaimana yang terdapat dalam UUD 1945 yakni: melindungi segenap bangsa Indonesia dan tumpah darah indonesia. Marpaung, L. (1992). Proses Penanganan Perkara Pidana. Jakarta: Sinar Grafika, h. 170.

${ }^{4}$ Soekanto, S. (2004). Pokok-Pokok Sosiologi Hukum. Jakarta: Raja Grafindo Persada, h. 4.

5 Lihat lebih jauh Iksan, M. (2017). Asas Legalitas Dalam Hukum Pidana: Studi Komparatif Asas Legalitas Hukum Pidana Indonesia Dan Hukum Pidana Islam (Jinayah). Jurnal Serambi Hukum, 11(01), h. 8.

6 Montesquieu. (1977). The Spirit of Laws. University of California Press. Anam, K, M. (2015). Teori Hukum Murni Dasar-Dasar Ilmu Hukum Normatif. Cetakan 7. Bandung: Nusa Media, h. 89.

7 Dalam declaration des droits d L'homme et du citoyen, asas ini dimasukkan dalam Pasal 4 Code Penal Perancis, di bawah pemerintahan Napoleon (1801), asas ini kemudian dikenal oleh Belanda, dan di tempat dalam Wetboek van Strafrecht Netherland (WvS) tahun 1881 dalam Pasal 1, kemudian Netherland Indie memuatnya dalam Pasal 1 WvS Netherland Indie 1918 di Indonesia. Moeljatno. (2002). Asas-Asas Hukum Pidana. Cetakan ke-tujuh. Jakarta: Rineka Cipta, h. 25. Lihat juga Rousseau, J, J. (1762). Du Contract Social, Ou Principes Du Droit Politique, Amsterdam. Hidayar, S, R, Husen, S, I. (2010). Perihal Kontrak Sosial atau Prinsip Hukum Politik, Cetakan Kedua. Jakarta: Dian Rakyat, h. 45.

$$
377 \text { | S A S I Vol. } 27 \text { No.3, Juli - September } 2021
$$


dalam suatu undang-undang). ${ }^{8}$ Asas legalitas dalam rumusan KUHPidana tersebut membawa konsekuensi kepada: Pertama, bahwa perbuatan seseorang yang tidak tercantum dalam undangundang sebagai tindak pidana tidak dapat dipidana; Kedua, ada larangan penggunaan analogi untuk membuat suatu perbuatan menjadi suatu tindak pidana sebagaimana dirumuskan dalam undang-undang; Ketiga, ketentuan undang-undang tidak berlaku surut. ${ }^{9}$

Sehubungan dengan pemaparan di atas, maka permasalahan yang menjadi fokus kajian adalah apakah yang dimaksud dengan Presiden dan/atau Wakil Presiden melakukan perbuatan tercela dalam konsep hukum pidana, sehingga dapat dimakzulkan. Kajian tentang pemakzulan Presiden dan/atau Wakil Presiden sebelumnya pernah dilakukan oleh Fachri, ${ }^{10}$ Hamdan Zoelva, ${ }^{11}$ Hufron $^{12}$ dan Sandijar, ${ }^{13}$ dalam penelitiannya telah dijelaskan alasan-alasan serta proses pemeberhentian Presiden dan/atau Wakil Presiden dalam masa jabatannya, namun belum memaknai perbuatan tercela sebagai alasan pemakzulan Presiden dan/atau Wakil Presiden dalam kaitannya dengan konsep hukum Pidana. Pembatasan makna perbuatan tercela ini sangat dibutuhkan, agar mendapatkan kepastian hukum dan menjadi acuan bagi masyarakat, Dewan Perwakilan Rakyat (DPR) dan Hakim Mahkamah Konstitusi (MK), untuk menilai perbuatan Presiden dan/atau Wakil Presiden yang dikatagorikan sebagai perbuatan tercela dalam Pasal 7A UUD 1945

\section{B. METODE PENELITIAN}

Menemukan jawaban dari permasalahan yang dikaji, maka digunakan penelitian hukum normatif, ${ }^{14}$ dengan tiga pendekatan, yakni: Pertama, pendekatan konseptual (conceptual approach). Kedua, pendekatan undang-undang (statute approach), dan Ketiga, pendekatan sejarah (historical approach). Jenis data yang dipakai adalah tediri dari: Bahan hukum primer, bahan hukum sekunder. Bahan tersier. Semua data yang dikumpukan kemudian, ${ }^{15}$ diolah dengan interpretasi (penafsiran) terhadap frasa perbuatan terela di Pasal 7A UUD 1945, konsep hukum Pidana serta melakukan analogi hukum. ${ }^{16}$

\section{PEMBAHASAN}

Istilah tindak pidana juga sering disebutkan dengan perbuatan pidana, ${ }^{17}$ ada juga yang

8 Sebagai dasar hukum Pidana, asas legalitas diatur dalam Buku I (satu) KUHPidana tentang Ketentuan Umum, yang membawa konsekuensi asas legalitas itu berlaku terhadap kejahatan-kejahatan yang diatur dalam Buku II maupun pelanggaran dalam Buku III KUHPidana dan berlaku juga bagi semua peraturan pidana yang diatur diluar KUHPidana, kecuali UU tersebut membuat penyimpangan (lex specialist derogat lex generalis). Ibid. Lihat juga Pasal 1 Ayat (1) dan (2) KUHPidana.

9 Ibid.

10 Fachri. (2019). Hakikat Putusan Mahkamah Konstitusi atas Pendapat Dewan Perwakilan Rakyat Mengenai Dugaan Pelanggaran Oleh Presiden dan/atau Wakil Presiden Menurut Undang-undang Dasar Negara Republik Indonesia Tahun 1945. Disertasi, Program Pascasarjana Fakultas Hukum Universitas Muslim Indonesia.

11 Zoelva, H. (2010). Pemakzulan Presiden di Indonesia. Disertasi, Program Pascasarjana Universitas Padjajaran.

12 Hufron. (2012). Pemberhentian Presiden dan/atau Wakil Presiden Menurut Undang-Undang Dasar Negara Republik Indonesia Tahun 1945. Disertasi, Program Doktor Fakultas Hukum Universitas Brawijaya.

13 Pebrihariati, S, R. (2013). Pemberhentian Presiden/Wakil Presiden dalam sistem ketatanegaraan di Indonesia. Disertasi, Program Pascasarjana Universitas Airlangga.

14 Sunggono, B. (2011). Metodologi Penelitian Hukum. Jakarta: Rajawali Pres, h. 94. Pres, h. 14.

5 Soekanto, S., Mamudji, S. (2006). Penelitian Hukum Normatif Suatu Tinjauan Singkat. Jakarta: Rajawali

16 Soemitro, R. H. (1982). Metodologi Penelitian Hukum. Semarang: Ghalia Indonesia, h. 24-25 dan h. $96-$ 97.

17 Simons mendefensikan hukum Pidana sebagai berikut: Pertama, hukum Pidana materil, yang mengandung petunjuk-petunjuk dan uraian tentang delict, peraturan-peraturan tentang syarat-syarat serta hal-hal yang dapat mempidanakan seseorang (strafbaarfeit), penunjukan tentang seorang yang dapat dipidana serta ketentuan tentang pidananya, hukum pidana materil juga mengatur tentang menetapkan siapa dan bagaimana orang dipidana; Kedua, hukum pidana formil adalah hukum yang mengatur tentang tata cara negara dengan perantaraan

$$
378 \text { | S A S I Vol. } 27 \text { No.3, Juli - September } 2021
$$


menyebutnya dengan peristiwa pidana yang berasal dari hukum pidana Belanda, yaitu: stafbaar feit dalam kata Latin disebut delict atau delectum. ${ }^{18}$ Tindak pidana terbagi atas tindak pidana umum, tindak pidana khusus, tindak pidana materil dan tindak pidana formil. ${ }^{19}$ Adapun pembenaran penjatuhan sanksi pidana, didasarkan pada: Pertama, teori absolut/pembalasan, dimana sanksi pidana diberikan karena pelaku telah melakukan tindak pidana; Kedua, teori relatif/doel theorien, yang menjelasakan bahwa dasar pemidanaan itu adalah alat untuk menegakkan hukum di masyarakat; Ketiga, teori gabungan/vereniging theorien, adalah pemidanaan yang berkarakter pembalasan dan pada sisi ide atau tujuannya adalah untuk perubahan prilaku pelaku kejahatan untuk dapat hidup lebih baik di tengah-tengah masyarakat. ${ }^{20}$

Hukum pidana tunduk pada asas legalitas, yakni: "vom psychologischen zwang," dengan menekankan agar dalam menentukan perbuatan-perbuatan yang dilarang UU Pidana, bukan saja tentang jenis perbuatan yang harus dituliskan dengan jelas, tetapi juga tentang pidana yang diancamkan. ${ }^{21}$ Dalam tradisi civil law system, ada empat aspek asas legalitas yang diterapkan secara ketat, yaitu: (1), peraturan perundang-undangan (law); (2) Non-retroaktif (retroactivity); (3) lex certa; dan (4) analogi. ${ }^{22}$

\section{Makna Perbuatan Tercela Dalam Kajian Hukum Pidana}

Andi Hamzah membuka ruang penggunaan analogi dalam hukum pidana, yaitu: Pertama, gesetz analogi adalah analogi terhadap perbuatan yang sama sekali tidak terdapat dalam ketentuan pidana; dan Kedua, recht analogi adalah analogi terhadap perbuatan yang mempunyai kemiripan dengan perbuatan yang dilarang dalam ketentuan hukum pidana. ${ }^{23}$ Jika dikaitkan dengan perbuatan tercela, Remmelink menjelsakan, bahwa untuk dapat dipidananya suatu perbuatan yang tercela harus ada ketentuan dalam undang-undang pidana yang merumuskan suatu perbuatan yang menjadi tindak pidana dan memberikan sanksi terhadap perbuatan tercela tersebut. $^{24}$

Di Indonesia, asas legalitas ini dapat diterapkan secara tidak kaku, dengan menjadikan

para pejabatnya menggunakan haknya untuk memidanakan. Baca lebih lengkap buku Hamzah, A. (2008). AsasAsas Hukum Pidana. Edisi Revisi. Jakarta: Rineka Cipta, h. 2-3. Criminal justice system di Indonesia terdiri atas komponen Kepolisian, Kejaksaan, Pengadilan Negeri dan Lembaga Pemasyarakatan sebagai aparat penegak hukum (tidak ada Mahkamah Konstitusi). Lihat juga Atmasasmita, R. (1996). Sistim Peradilan Pidana. Bandung: Binacipta, h. 32.

18 Baca lebih lanjut buku Suhartoyo. (2019). Argumen Pembalikan Beban Pembuktian Sebagai Metode Prioritas dalam Pemberantasan Tindak Pidana Korupsi dan Tindak Pidana Pencucian Uang. Depok: Raja Grafindo Persada, h. 19-28.

19 Di Indonesia tindak pidana umum adalah semua delik yang terdapat dalam KUHPidana beserta semua perundang-undangan yang mengubah dan menambah KUHPidana. Sedangkan pidana khusus adalah semua perundang-undangan diluar KUHPidana beserta perundang-undangan pelengkapnya, baik perundang-undangan pidana maupun yang bukan pidana, tetapi bersanksi pidana (perundang-undangan khusus). Ibid.

20 Atmadja, I. G. D., Budiartha, I. P. N. (2018). Teori-Teori Hukum. Malang: Setara Press, h. 175-177.

21 Teori tentang asas legalitas ini disampaikan Von Feurbach. Baca buku Moeljatno. (2002). Op.Cit.

22 Menurut Roelof H. Haveman, keempat aspek asas legalitas tersebut dapat dijelaskan sebagai berikut: Pertama, Lex Scripta adalah pemidanaan harus didasarkan pada undang-undang; Kedua, Lex Certa adalah jelas dan rinci dalam kaitannya dengan hukum yang tertulis, pembuat undang-undang (legislatif) harus merumuskan secara jelas dan rinci mengenai perbuatan yang disebut dengan tindak pidana (kejahatan, crimes); Ketiga, analogi artinya memperluas berlakunya suatu peraturan dengan mengabstraksikannya menjadi aturan hukum yang menjadi dasar dari peraturan itu (ratio legis) dan kemudian menerapkan aturan yang bersifat umum ini kepada perbuatan konkrit yang tidak diatur dalam undang-undang; Keempat, Non-retroaktif adalah bahwa ketentuan peraturan perundang-undangan yang merumuskan tindak pidana tidak dapat diberlakukan secara surut. Baca lebih lanjut Iksan, M. 2017. Op.Cit., h. 8-10.

23 Pendapat Andi Hamzah ini didasarkan pada para pakar, seperti: Hazewinkel-Suringa, Roland Freisler, Vos, Pompe, Paul Scholten, Utrecht, Taverne dan Wijers. Lihat dalam buku Hamzah, A. (2008). Op.Cit., h. 44-54.

24 Remmelink, J. (2003). Hukum Pidana: Komentar Atas Pasal-pasal Terpenting dari Kitab UndangUndang Hukum Pidana Belanda dan Padanannya dalam Kitab Undang-undang Hukum Pidana Indonesia. Jakarta: Gramedia, h. 599.

379 |S A S I Vol. 27 No.3, Juli-September 2021 
hukum Adat atau hukum yang hidup di masyarakat (the living law) menjadi sumber hukum pidana, selain KUHPidana. ${ }^{25}$ Sebab di Indonesia suatu tindak pidana dapat dikategorikan pada perbuatan tercela dan perbuatan melawan hukum. ${ }^{26}$ Sebagai salah satu unsur mutlak dari suatu delik, perbuatan melawan hukum dicantumkan dalam Pasal 1 ayat (1) KUHPidana, penegasan ini merupakan asas legalitas formal (nulla poena sine lege), yang bertujuan untuk memberikan kepastian hukum. ${ }^{27}$ Dengan demikian, apabila terdapat perbuatan (Presiden/Wakil Presdien) yang menurut masyarakat tercela sehingga patut untuk dipidana, maka perbuatan tersebut tidak dapat dipidana apabila ternyata belum ada perundang-undangan yang merumuskan perbuatan tercela tersebut sebagai delik. ${ }^{28}$

\section{Asas Legalitas Perbuatan Tercela Dalam Perspektif Konstitusi (UUD 1945)}

Terkait asas legalitas materil dan asas legalitas formal, di Indonesia kedua asas tersebut dapat berjalan beriringan, sebab nilai-nilai hukum Adat atau hukum yang hidup di masyarakat itu sendiri secara legal formal sudah menjadi sumber dari segala sumber hukum di Indonesia, melalui Pancasila sebagai "roh" dari UUD 1945. ${ }^{29}$ Pendapat ini sejalan dengan politik hukum pembentukan sistem hukum pidana dalam Rancangan Undang-Undang Hukum Pidana (RUUKUHPidana) di Indonesia, yang beradab dan disesuaikan dengan budaya bangsa Indonesia yang didasarkan Pancasila dan UUD 1945. ${ }^{30}$ Dengan perspektif demikian, maka seseorang Presiden/Wakil Presiden di Indonesia dapat saja diadili dan dijatuhi pidana tanpa harus melanggar ketentuan hukum pidana yang telah ada, tetapi sudah cukup apabila perbuatan tersebut dipandang sebagai perbuatan yang tercela oleh masyarakat, dengan batu ujinya adalah nilai-nilai yang terkandung dalam Pancasila dan UUD 1945. ${ }^{31}$

25 Asas subsidiaritas adalah asas UU Pidana harus diartikan seluas-luasnya dan tidak hanya mengenai pidananya saja, tetapi mengenai segala sesuatunya dari peraturan itu yang mempunyai pengaruh terhadap penilaian tindak pidana, penentuannya harus dilakukan in concreto dan tidak in abstracto, ketentuan yang demikian terdapat dalam: (1) UU No. 1 /Drt/1951 tentang Tata Susunan Lembaga Peradilan; (2) UU No. 19 Tahun 1964 tentang Kekuasaan Kehakiman; UU No. 14 Tahun 1970 tentang Ketentuan Pokok-pokok Kekuasaan Kehakiman; UU No. 35 Tahun 1999 tentang Perubahan terhadap UU No. 14 Tahun 1970; UU No. 4 Tahun 2004 tentang Kekuasaan Kehakiman; (3) Pasal 24 UUD 1945. Iksan, M. (2017). Op.Cit., h. 16.

26 Pohan, A, dkk. (2012). Hukum Pidana Dalam Perspektif. Edisi Pertama. Denpasar: Pustaka Larasan, h. $115-125$.

27 Melawan hukum dalam hal ini diartikan sebagai bertentangan dengan perundang-undangan (legalitas formal), yang dianut dari Code Penal Perancis. Adapun legalitas materil adalah merupakan dasar dalam memberlakukan hukum yang hidup di masyarakat, sehingga penentu perbuatan tercela sebagai perbuatan pidana harus didasarkan pada kondisi konkrit masyarakat. Supusesa, R. (2012). Eksistensi Hukum Delik Adat Dalam Perspektif Pembaharuan Hukum Pidana Di Maluku Tengah. Jurnal Mimbar Hukum, 24(1), 41-54. h. 51.

28 Nurdin, F. S. (2016). Rekonstruksi Asas Legalitas Dalam Hukum Pidana Berdasarkan Prinsip Keadilan, Jurnal Refleksi Hukum, 1 (1), h. 8. Asas legalitas (principle of legality) biasa dikenal dalam bahasa Latin dengan nullum delictum nulla poena sine praevia lege (tidak ada delik, tidak ada pidana tanpa peraturan lebih dahulu), adagium ini berasal dari Von Feuerbach. Moeljatno (2002). Op.Cit., h. 23.

29 Delik; Delict; Delikt; Strafbaar Feit; Offence, Crminal act adalah istilah yang umum digunakan dalam peraturan perundang-undangan di Indonesia yang dimaknai sebagai "tindak pidana," menurut Andi Hamzah istilah delik juga dimaknai dengan tanpa berbuat atau tidak bertindak yang disebut pengabaian, dalam bahasa Belanda adalah nalaten dan bahasa Inggris negligence atau perbuatan yang diharuskan. Hamzah A. (2008). Terminologi Hukum Pidana, Edisi Pertama. Cetakan Pertama. Jakarta: Sinar Grafika, h. 47. Jadi ketika Presiden/Wakil Presiden mengabaikan atau tidak berbuat sesuatu yang sudah diperintahkan (diamanahkan) oleh konstitusi (UUD 1945) dan peraturan perundang-undangan lainnya, maka Presiden/Wakil Presiden dapat dimaknai telah melakukan delik.

30 Tujuan Pembentuk RUU KUHPidana adalah dekolonisasi dan konsolidasi. Dekolonisasi mengandung makna melakukan formulasi ulang atau reformulasi terhadap berbagai kejahatan yang diatur, sedangkan konsolidasi adalah menghimpun dan mensistematisasi berbagai tindak pidana, baik yang ada dalam KUHPidana maupun di luar KUHPidana dalam suatu kitab undang-undang, namun demikian, rekodifikasi dan konsolidasi dalam RUUHPidana tetap memberi peluang tumbuh dan berkembangnya kejahatan dimensi baru di kemudian hari, dengan tetap mengacu kepada asas-asas yang terkandung dalam Buku Kesatu KUHPidana. Lihat Imran, Hidayati, F. R. (2019). Memperkuat Peradaban Hukum dan Ketatanegaraan Indonesia. Cetakan Pertama. Jakarta: Sekretariat Jenderal Komisi Yudisial Republik Indonesia, h. 250-251.

31 Namun, ajaran sifat melawan hukum materil dalam penjelasan Pasal 2 ayat (1) UU No. 31 Tahun 1999 tentang Pemberantasan Tindak Pidana Korupsi telah dinyatakan tidak mengikat dan bertentangan dengan UUD

380 |S A S I Vol. 27 No.3, Juli - September 2021 
Sebab itu, pedoman untuk menentukan sumber hukum materil yang dapat dijadikan sebagai bahan hukum (sumber legalitas) tersebut adalah sepanjang sesuai dengan nilai-nilai Pancasila dan/atau UUD 1945..$^{32}$ Asas berikutnya terkait dengan perbuatan tercela adalah pertanggungjawaban, yakni: siapa yang berbuat, maka dia yang mempertangungjawabankan perbuatannya, suatu perbuatan tercela sebagai tindak pidana dan bentuk pertanggunganjawabnya harus memperoleh pengaturan yang jelas dalam undang-undang. ${ }^{33}$ Berikutanya asas yang fundamental dalam hukum pidana adalah asas kesalahan, seseorang dikatakan bersalah apabila ia dapat dicela dari penilaian moral, sebab ia dianggap semestinya dapat berbuat patut, sedang yang dimaksud dengan kesalahan ialah keadaan jiwa seseorang yang melakukan perbuatan itu dalam hubungannya dengan perbuatannya, dan hubungan itu sedemikian rupa, shingga ia dapat dicela atas perbuatannya, demikian pula apabila Presiden/Wakil Presiden dicela atas perbuatannya, maka ia dapat di hukum. ${ }^{34}$ Karenanya, ilmu hukum pidana menilai apakah asas-asas hukum pidana telah sesuai dengan tata susila dan jiwa bangsa, serta menilai apakah peraturan-peraturan yang berlaku sejalan dengan asas-asas yang telah ada. ${ }^{35}$

\section{Unsur-Unsur Perbuatan Tercela Menurut Konsep Hukum Pidana}

Secara luas, unsur-unsur strafbaar feit, terdiri dari: (1) orang sebagai pelaku; (2) perbuatan bersifat melawan hukum; (3) kesalahan dan pidana. Adapun dalam arti sempit adalah unsur-unsur dari setiap tindak pidana sebagai prilaku menyimpang baik yang di atur dalam KUHPidana ataupun di luar KUHPidana. ${ }^{36}$ Mengenai unsur-unsur delik, para ahli hukum pidana sepakat membagi dua jenis, yaitu: unsur objektif dan unsur subjektif. Unsur objektif adalah perbuatan pidana yang mengacu pada asas legalitas (terdapat dalam KUHPidana), adapun unsur subjektif terletak pada pelaku yang mengacu pada asas culvabilitas/kesalahan,

1945, berdasarkan Putusan MK RI No. 003/PUU-IV/2006 tentang Pengujian UU No. 31 tahun 1999 tentang Pemberantasan Tindak Pidana Korupsi sebagaimana telah diubah dengan UU No. 20 Tahun 2001. Putusan MK tersebut menyatakan: bahwa sepanjang frasa yang berbunyi "secara melawan hukum" dalam Pasal ini mencakup perbuatan melawan hukum dalam arti formil maupun dalam arti materil, yakni meskipun perbuatan tersebut tidak diatur dalam peraturan perundang-undangan, namun apabila perbuatan tersebut dianggap tercela karena tidak sesuai dengan rasa keadilan atau norma-norma kehidupan sosial dalam masyarakat, maka perbuatan tersebut dapat dipidana, bertentangan dengan UUD 1945. Selain itu juga diputus bahwa: Penjelasan Pasal 2 ayat (1) UndangUndang Republik Indonesia Nomor 31 Tahun 1999 tentang Pemberantasan Tindak Pidana Korupsi tidak mempunyai kekuatan hukum mengikat. Sebab hal tersebut sangat bertentangan dengan KUHPidana yang menjunjung tinggi asas legalitas yang merupakan asas yang sangat fundamental dalam hukum pidana. Sudirman, A. (2009). Eksistensi Hukum Dan Hukum Pidana Dalam Dinamika Sosial Suatu Kajian Teori Dan Praktik Di Indonesia. Semarang: BP UNDIP, h. 53-54.

32 Argumentasi ini berdasar dari doktrin "the general principle of law recognized by the community of nations" yang terdapat dalam Pasal 15 Ayat (2) International Covenant on Civil and Political Right (ICCPR), yang menegaskan bahwa suatu perbuatan dinyatakan sebagai tindak pidana adalah perbuatan yang dilarang dan diancam pidana oleh peraturan perundang-undangan, yang harus juga bersifat melawan hukum atau bertentangan dengan hukum yang hidup dalam masyarakat, hal demikian ini adalah baru dalam konsep hukum pidana di Indonesia, sebab ketentuan umum seperti itu tidak ada dalam KUHPidana. Lihat lebih jauh dalam Badan Pembinaan Hukum Nasional. (2015). Naskah Akademik Rancangan Undang-Undang Tentang Kitab Undang-Undang Hukum Pidana (KUHP). Jakarta: Kementerian Hukum dan Hak Asasi Manusia Republik Indonesia, h. 28-29.

33 Adapun yang dimaksud dengan pertanggunganjawaban pidana adalah diteruskannya perbuatan tercela tersebut yang secara objektif ada pada tindak pidana berdasarkan ketentuan hukum yang berlaku, dan secara subjektif kepada pembuat yang memenuhi syarat dalam KUHPidana, untuk dapat dikenai pidana karena perbuatannya, maka timbullah pertanggungjawaban pidana. Ibid. Lihat juga Jafar, W. A. (2016). Analisis Asas Hukum Pidana Islam Dan Asas Hukum Pidana Di Indonesia. Al-Istinbath: Jurnal Hukum Islam, 1(1), 25-44. h. 31.

34 Ibid.

35 Baca lebih lengkap buku Mertha I. K, dkk. (2016). Buku Ajar Hukum Pidana, Denpasar: Fakultas Hukum Universitas Udayana, h. 28.

36 Untuk menentukan unsur-unsur yang seharusnya melekat dalam setiap tindak pidana, para sarjana berbeda pendapat, inti perbedaan tersebut yaitu: (1) Paham monistis, menyatukan semua unsur yang ada untuk menetukan adanya tindak pidana, sedangkan paham dualistis, memisahkan unsur yang dikatagorikan sebagai perbuatan pidana dengan kesalahan. Ibid., h. 101-102.

$$
381 \text { |S A S I Vol. } 27 \text { No.3, Juli- September } 2021
$$


kedua unsur ini adalah penentu untuk dapat atau tidaknya seseorang dipidana. ${ }^{37}$

Argumentasi ini sejalan dengan keseimbangan asas legalitas formal dan materil. Dengan demikian, tindak pidana diarikan sebagai: Pertama, perbuatan melakukan atau tidak melakukan sesuatu yang oleh peraturan perundang-undangan dinyatakan sebagai perbuatan yang dilarang dan diancam pidana; Kedua, suatu tindak pidana harus bersifat melawan hukum atau bertentangan dengan hukum yang hidup dalam masyarakat; Ketiga, setiap tindak pidana selalu dipandang bersifat melawan hukum, kecuali ada alasan pembenar. ${ }^{38}$ Intinya tindak pidana itu memiliki empat unsur, yakni: (1) Perturan; (2) Perbuatan; (3) Pelaku; dan (4) Pidana (sanksi/hukuman). ${ }^{39}$ Pendapat senada disampaikan Moeljatno, R.Tresna, Vos Adami, ${ }^{40}$ dan Lamintang. ${ }^{41}$

Adapun yang terkait dengan unsur melawan hukum dalam konsep hukum pidana mempunyai dua sifat, yakni: sifat melawan hukum formil dan materil. Sifat melawan hukum formal adalah perbuatan yang bertentangan dengan hukum yang berisikan norma perintah dan larangan, sedangkan sifat melawan hukum materil adalah pelanggaran terhadap kepentingankepentingan sosial yang dilindungi oleh norma-norma hukum perorangan atau masyarakat, termasuk kerusakan atau membahayakan suatu kepentingan umum. ${ }^{42} \mathrm{Di}$ Indonesia disepakati bahwa the living law adalah sumber hukum positif, baik melalui legislasi maupun putusan hakim, Mochtar Kusumaatmadja, mengatakan: "selain hukum, kehidupan manusia dalam masyarakat berpedoman pada moral, yang diatur oleh agama, kaidah-kaidah susila, kesopanan, adat kebiasaan dan kaidah-kaidah sosial lainnya."

Hubungan hukum tidak tertulis dan hukum tertulis tersebut adalah sebagai penilai terhadap suatu perbuatan tercela, yang dapat menentukan apakah yang harus dilakukan seseorang (Presiden/Wakil Presiden) dan apakah yang harus dihindarinya. Namun, menurut Schaffmeister, Keijzer, dan Sutorius, perbuatan tercela tersebut harus diatur dalam hukum tertulis, sebab tidak dapat dijatuhkan pidana karena suatu perbuatan yang tidak termasuk dalam rumusan delik, dengan memenuhi dua unsur, yaitu: perbuatan itu bersifat melawan hukum dan dapat dicela. ${ }^{44}$

Selanjutnya sifat subjektif dari hukum pidana adalah adanya kesalahan (schuld), yakni: mengenai keadaan atau gambaran batin orang sebelum atau pada saat memulai perbuatan tercela, karena itu unsur ini selalu melekat pada diri pelaku. Hanya orang yang dapat diminta

37 Remmelink, J. (2003). Op.Cit., h. 61.

38 Lihat Badan Pembinaan Hukum Nasional. (2015). Op.Cit.

39 Maramis, F. (2016). Hukum Pidana Umum dan Tertulis Indonesia. Edisi ke-1. Cetakan Ke-3. Depok: Raja Grafindo Persada, h. 13.

40 Pendapat Jonkers sedikit berbeda dengan menyatakan unsur perbuatan pidana (tercela) terdiri dari: perbuatan (yang); melawan hukum (yang berhubungan dengan); kesalahan (yang dilakukan oleh orang yang dapat); dipertanggungjawabkan. Chazawi, A. (2011). Pelajaran Pidana Bagian 1. Edisi ke-1. Cetakan ke-6. Jakarta: Raja Grafindo Persada, h. 81.

41 Unsur objektif adalah unsur yang berhubungan dengan keadaan-keadaan dari si pelaku, meliputi: (1) Perbuatan manusia, yang terbagi atas perbutan yang bersifat positif dan bersifat negatif yang menyebabkan suatu pelanggaran pidana; (2) Akibat perbuatan manusia, maksudnya adalah akibat yang terdiri atas merusaknya atau membahayakan kepentingan-kepentingan hukum, yang menurut norma hukum pidana mendapakan sanksi; (3) Keadaan-keadaan di sekitar perbuatan itu; (4) Sifat melawan hukum dan sifat dapat dipidana. Sofyan, A, Azisa, N. (2016). Op.Cit., h. 99-102.

42 Sesungguhnya dalam KUHPidana tidak secara tegas dirumuskan, namun dapat ditemukan dalam beberapa pengertian antara lain Pasal 167, Pasal 522 mengandung makna "bertentangan dengan hukum," Pasal 406 dengan rumusan "tanpa hak sendiri," kemudian Pasal 333 dengan norma yang menyebutkan "bertentangan dengan hukum objektif.” Baca lebih lengkap Sudharmawatiningsih. (2007). Sifat Melawan Hukum Materil Dalam Tindak Pidana Korupsi (Respon Terhadap Putusan Mahkamah Konstitusi). Jurnal Hukum Dan Dinamika Masyarakat, 5(1), h. 11.

43 Kusumaatmadja, M. (2006). Konsep-Konsep Hukum Dalam Pembangunan. Cetakan ke-2. Bandung: Alumni, h. 4.

${ }^{44}$ Andi Sofyan, A, Azisa, N. (2016). Op.Cit.

382 |S ASI Vol. 27 No.3, Juli - September 2021 
pertanggungjawaban saja yang dapat dipersalahkan, orang yang kurang sempurna akalnya atau sakit jiwa (gila) tidak dapat diminta pertanggung jawaban atas perbuatannya, karena itu tidak dapat dipersalahkan. ${ }^{45}$ Sebab pertanggungjawaban pidana adalah diteruskannya celaan yang objektif ada pada tindak pidana dan secara subjektif kepada seseorang yang memenuhi syarat untuk dapat dijatuhi pidana karena perbuatannya. ${ }^{46}$

Beranjak dari pemaparan yang telah disampaikan, jika dihubungkan dengan unsur-unsur perbuatan tercela yang terdapat pada Pasal 7A UUD 1945, maka diperoleh pengertian, Pertama, unsur-unsur perbuatan tercela Presiden/Wakil Presiden dalam Pasal 7A UUD 1945, terdiri dari: (1) Perturan, dalam Pasal 7A UUD 1945; (2) Perbuatan, pelanggaran sumpah/janji jabatan; (3) Pelaku, Presiden/Wakil Presiden; dan (4) Sanksi/hukuman, dimakzulkan; Kedua, unsur objektif perbuatan tercela Presiden/Wakil Presiden, sebagai berikut: (1) Perbuatan Presiden/Wakil Presiden yang tidak mau memenuhi kewajiban hukum sumpah/janji jabatannya dan perbuatan yang bertentangan dengan kewajiban hukum sumpah/janji jabatannya; (2) Akibat Presiden/Wakil Presiden tidak memenuhi sumpah/janji, menyebabkan tidak terpenuhinya dan/atau hilangnya hak-hak konstitusional rakyat, sehingga membahayakan kepentingankepentingan hukum; (3) Keadaan-keadaan di sekitar perbuatan tercela itu adalah Presiden/Wakil Presiden seharusnya mampu dan/atau dapat memenuhi sumpah/janji jabatanya, namun ia tidak mau melakukannya; (4) Sifat melawan hukumnya adalah melanggar Pasal 9 Ayat (1) UUD 1945 tentang sumpah/janji jabatan Presiden/Wakil Presiden; ${ }^{47}$

Ketiga, unsur subjektif dari perbuatan tercela Presiden/Wakil Presiden adalah adanya kesalahan, yakni mengenai keadaan batin Presiden/Wakil Presiden sebelum atau pada saat melakukan pelanggaran sumpah/janji dalam keadaan sadar, sehat jasmani/rohani (tidak gila) dan tanpa paksaan, sehingga dapat diminta pertanggung jawaban; Keempat, semua perbuatan yang melanggar delik hukum Pidana adalah perbuatan tercela, dan sanksinya adalah pidana sesuai dengan KUHPidana, sehingga perbuatan tercela yang sudah diatur secara formal dalam KUHPidana bukanlah makna perbuatan tercela yang dimaksud dalam Pasal 7A UUD 1945, sebab sudah ditentukan limitatif perbuatan pidana yang dapat memberhentikan Presiden/Wakil Presiden dalam masa jabatannya, yakni: korupsi, penyuapan, dan tindak pidana berat lainnya. ${ }^{48}$

45 Pembuat undang-undang menganggap, bahwa orang pada umumnya sehat, sehingga bila ia melakukan perbuatan tercela (melanggar norma pidana) dapat diminta pertanggungjawaban. Barulah jika timbul keraguraguan tentang keadaan jika seseorang, maka diadakan penyelidikan lebih lanjut. Tentang tanggung jawab orang ini diatur dalam Pasal 44 KUHPidana yang menegaskan, "barang siapa melakukan suatu perbuatan yang tidak dapat dipertanggung jawabkan kepadanya karena kurang sempurna akalnya atau karena sakit berobah akalnya tidak boleh dipidana." Oleh karena itu, suatu asas pokok dari hukum pidana adalah "tidak ada pidana tanpa kesalahan." Kesalaahan dalam arti hukum pidana mengandung beban pertanggungjawaban pidana, yang terdiri atas kesengajaan (dolus) dan kelalaian (culpa). Sebagai contoh suatu kesengajaan terdapat pada Pasal 338 KUHPidana tentang pembunuhan, sedangkan kelalaian dapat dirumuskan dalam Pasal 359 KUHPidana, yaitu menyebabkan mati. Ibid.

46 Maroni. (2015). Pengantar Hukum Pidana Administrasi. Bandar Lampung: Anugrah Utama Raharja, h. 88.

47 Terkait dengan unsur sifat melawan hukum (wederrechtelijkheid) suatu tindak pidana yang bersifat objektif, terdiri dari dua jenis sifat, yaitu: sifat melawan hukum formal (formale wederrechtelijkheid) dan sifat melawan hukum materil (matereile wederrechtelijkheid). Sifat melawan hukum formal terjadi karena memenuhi rumusan undang-undang (delik) tertulis, sifat melawan hukum formal merupakan syarat untuk dapat dipidananya perbuatan, jika ada alasan-alasan pembenar, maka alasan-alasan tersebut harus juga disebutkan secara tegas dalam undang-undang. Adapun sifat melawan hukum materil dalam hukum pidana Indonesia adalah yang terdapat dalam hukum adat dan hukum agama (delik adat dan delik agama), atau perbuatan tercela meskipun belum diatur dalam undang-undang, namun bertentangan dengan asas-asas hukum secara umum, sifat melawan hukum itu dapat dihapuskan berdasar ketentuan undang-undang maupun aturan tidak tertulis. Ajaran materil juga menyatakan, di samping memenuhi syarat-syarat formil, perbuatan itu juga harus benar-benar dirasakan oleh masyarakat sebagai perbuatan yang tidak patut atau tercela. Sulistia, T. (2014). Hukum Pidana. Jakarta: Raja Grafindo Persada, h. 6772.

48 Terkait dengan kesalahan (sehuld) sebagai perbuatan tercela yang dapat diminta pertanggungjawaban pidana, serta patut untuk mendapatkan hukuman dalam konsep hukum pidana, sebagai berikut: (1) Kesalahan

383 |S A S I Vol. 27 No.3, Juli - September 2021 
Terkait dengan hubungan kewajiban memenuhi sumpah/janji dan kesalahan Presiden/Wakil Presiden, Moeljatno menjelasakan bahwa seseorang (Presiden/Wakil Presiden) dapat dikatakan mempunyai kesalahan, jika perbuatan tersebut, dilihat dari segi masyarakat dapat dicela, yaitu: mengapa melakukan perbuatan tercela (tidak memenuhi sumpah/janji) yang merugikan masyarakat, padahal dia mampu dan seharusnya dia dapat, bahkan harus menghindar dari perbuatan tercela tersebut. Dengan demikian tentu saja perbuatan tercela itu sengaja dilakukannya, seseorang juga dapat dicela meskipun tidak sengaja (alpa) atau lalai terhadap kewajiban yang oleh masyarakat dipandang seharusnya dijalankan olehnya (Presiden/Wakil Presiden). ${ }^{49}$

Berdasar pendapat Moeljatno, maka dapat ditarik pengertian: Pertama, makna perbuatan tercela Presiden/Wakil Presiden adalah semua perbuatan yang memenuhi rumusan undangundang yang tertulis; Kedua, perbuatan yang dilakukan oleh Presiden/Wakil Presiden tersebut menurut masyarakat Indonesia dapat dicela baik menurut adat istiadat maupun agama serta merugikan masyarakat ${ }^{50}$ Ketiga, ketika melakukan perbuatan tercela tersebut Presiden/Wakil Presiden mengerti dan sadar baik secara jasmani maupun rohani (psikologis) bahwa perbuatan itu merugikan masyarakat, namun dia tetap melakukannya, sehingga dia dicela oleh masyarakat meskipun tidak sengaja atau karena lalai (alpa) terhadap kewajibannya. ${ }^{51}$

Pengertian perbuatan tercela sebagaimana yang dikemukakan di atas senada dengan Herman Mennheim yang mengatakan bahwa: "Penal Code is the most faithful mirror of civilization of a nation," jika dielaborasi jenis-jenis delik yang ada dalam KUHPidana berbagai negara, maka didapatkan adanya delik-delik yang dipandang netral, artinya semua negara memandang sama perbuatan tercela, seperti: pencurian, pembunuhan, pemerkosaan, penipuan, penganiayaan, pelanggaran sumpah/janji dan sejenisnya dapat dipidana. ${ }^{52}$ Namun, tidak selalu

adalah keseluruhan syarat yang memberikan dasar adanya pencelaan pribadi terhadap pelaku; (2) Kesalahan adalah terdapatnya keadaan psikologis tertentu pada seseorang yang melakukan perbuatan dan adanya hubungan antara keadaan tersebut dengan perbuatan yang dilakukannya itu, sehingga orang tersebut dapat dicela; (3) Kesalahan pada hakekatnya adalah tidak dihindarinya perbuatan melawan hukum sehingga mengakibatkan si pelaku dapat dicela dari akibatnya perbuatannya. Pendapat ini disampaikan oleh Metzger, Simon, Pompe dan Van Hamel. Ibid.

49 Ibid., h. 79-80.

50 Oleh sebab itulah Presiden/wakil Presiden sebelum memangku jabatannya harus bersumpa atau berjanji dengan sungguh-sungguh akan memenuhi kewajiban Presiden Republik Indonesia (Wakil Presiden Republik Indonesia) dengan sebaik-baiknya dan seadil-adilnya, memegang teguh Undang-Undang Dasar dan menjalankan segala undang-undang dan peraturannya dengan selurus-lurusnya serta berbakti kepada Nusa dan Bangsa, supaya tidak melakukan perbuatan-perbuatan yang merugikan masyarakat, karena semua keingginan masyarakat secara sudah terumuskan dalam kosntitusi (UUD 1945) dan serta dalam semua undang-undang dan peraturannya. Dengan pengertian ini juga, maka pelanggaran atau tidak dapat memenuhi sumpah atau janji adalah makna lain dari perbuatan tercela Presiden dan atau Wakil Presiden, sebab Presiden dan atau Wakil Presiden telah melakukan sumpah palsu. Lihat Pasal 9 UUD 1945. Lihat juga Pasal 6 UUD 1945 yang mengharuskan calon Presiden/calon Wakil Presiden harus seorang warga negara Indonesia sejak kelahirannya dan tidak pernah menerima kewarganegaraan lain karena kehendaknya sendiri, tidak pernah mengkhianati negara.

51 Argumentasi inilah yang mendasari UUD 1945 (konstitusi) mengharusan bagi calon Presiden/calon Wakil Presiden harus mampu secara rohani dan jasmani untuk melaksanakan tugas dan kewajiban sebagai Presiden/Wakil Presiden, sebab kesalahan (dalam arti perbuatan tercela) berkaitan erat dengan pertanggungjawaban hukum, misalnya orang gila (tidak sehat rohani dan jasmaninya), orang yang terpaksa atau di bawah pengaruh/ancaman orang lain tidak dapat diminta pertanggungjawaban hukum. Sebagai contoh: Presiden/Wakil Presiden yang di bawah ancaman atau todongan senjata, sehingga melakukan perbuatan yang dilarang atau bertentangan dengan kosntitusi (UUD 1945) dan/atau peraturan perundang-undangan lainnya, yang mengakibatkan Presiden/Wakil Presiden tidak dapat memenuhi kewajibannya dengan sebaik-baiknya dan seadiladilnya, tidak lagi memegang UUD 1945 dan menjalankan segala undang-undang serta peraturannya dengan selurus-lurusnya serta tidak mampu lagi berbakti kepada Nusa dan Bangsa, maka tidak dapat diminta pertanggungjawaban. Sebaliknya, Presiden/Wakil Presiden yang tidak berada dalam keadaan demikian, namun tetap melakukan perbuatan tercela, maka sudah layak dan pantas untuk dimakzulkan, sebab sehat rohani dan jasmani, serta dapat diminta pertanggungjawaban hukum. Ibid., h. 80.

52 Delik-delik seperti ini terdapat pada KUHPidana semua negara tanpa melihat ideology, budaya, adat, dan agama. Delik-delik baru sebagai akibat dari kemajuan teknologi, seperti delik computer, internet, media sosial elektronik, pembajakan udara, delik cyber, many laundering, penyadapan telepon, perekaman pembicaraan tanpa

$$
384 \text { | S A S I Vol. } 27 \text { No.3, Juli - September } 2021
$$


ukuran nilai perbuatan tercela itu masuk KUHPidana, kepentingan ketertiban umum atau konstitusi juga dapat dijadikan delik, contohnya penghinan terhadap pejabat negara, bendera, atau lambang negara dan seterusnya. ${ }^{53}$ Sebaliknya ada perbuatan tercela, tetapi tidak perlu masuk ke dalam KHUPidana, misalnya suka berhutang, suka berbohong, tidak amanah, ingkar janji (sumpah paslu), dan sejenisnya, sanksi dalam perbuatan tercela seperti ini lebih tetap diberikan dalam hukum hukum tata negara atau perdata. ${ }^{54}$

\section{Makna Perbuatan tercela Pada Pasal 7A UUD 1945 Dalam Konsep Hukum Pidana}

Dengan adanya batasan yuridis, suatu perbuatan tercela yang sudah memenuhi rumusan delik dalam undang-undang tidak serta merta dapat dinyatakan sebagai tindak pidana. Untuk dapat dinyatakan sebagai tindak pidana, perbuatan tercela (melawan hukum secara formal), harus juga bersifat melawan hukum secara materil, dengan kata lain ketiadaan sifat melawan hukum (absence of unlawfulness) mempunyai konsekuensi perbuatan pidana tersebut tidak dapat dipidana, sebab syarat pidana juga merupakan pernyataan tercela kepada diri si pelaku. ${ }^{55}$

Sehubungan dengan hal tersebut, maka alasan yang paling logika untuk menilai suatu perbuatan tercela adalah perbuatan yang melanggar norma-norma, baik dalam bentuk norma hukum, norma masyarakat, norma agama dan adat budaya, ${ }^{56}$ oleh sebab itu asas hukum pidana dalam konsep RUU KUHPidana adalah berlandaskan pada pokok pemikiran sistem hukum nasional yang berpangkal pada asas keseimbangan nilai-nilai dalam Pancasila (UUD 1945) dan asas keseimbangan tujuan pembangunan nasional, yaitu: keseimbangan antara "perlindungan masyarakat" (social defence) dan "kesejahteraan masyarakat " (social welfare). ${ }^{57}$

Secara teori, KUHPidana berisi tentang larangan perbuatan yang buruk, tentang nilainilai kesusilaan dan agama (das recht ist das ethische minimum) dari suatu masyarakat, karena perbuatan yang diatur merupakan perbuatan yang dianggap tercela dan asusila, karenanya harus dikenai sanksi sebagai bentuk tangung jawab. ${ }^{58}$ Pemberian sanksi atas kesalahannya ditujukan

izin, delik lingkungan hidup, terorisme, narkotika, dan sejenisnya juga bersifat netral. Hamzah, A. (2008). Perbandingan Hukum Pidana Beberapa Negara. Edisi Ketiga. Cetakan Ketiga. Jakarta: Sinar Grafika, h. 6-8.

${ }^{53}$ Pasal 207 KUHPidana berada di dalam Bab VIII yang berujudul Kejahatan terhadap Penguasa Umum. Bab ini dimulai dari Pasal 207 sampai dengan Pasal 241. Meski demikian beberapa pasal sudah dicabut, yaitu: Pasal 230 dan 241 Ayat (1). Delik-delik yang diatur dalam Bab ini diantaranya adalah delik penghinaan terhadap penguasa/badan umum, perbuatan yang mengancam kepada harkat dan martabat penguasa atau pejabat, termasuk juga delik-delik penyuapan, memaksa pejabat atau penguasa umum melakukan sesuatu atau tidak melakukan sesuatu yang bertentangan dengan jabatannya, melawan atau menghalangi pejabat yang sedang menjalankan tugas, tidak mau hadir dipanggil sebagai saksi atau ahli oleh pengadilan dan beberapa delik liannya. Delik yang diatur dalam Pasal 207 KUHPidana ini merupakan delik yang ditujukan kepada pejabat, dan jabatan atau penguasa umum sebagai delik formil, artinya delik ini sempurna sebagai delik ketika perbuatan yang terlarang tersebut dilakukan. Dalam kaitan dengan hal tersebut setidaknya ada 3 pasal yang bisa ditafsirkan sebagai delik materil, yaitu: Pasal 213 dan 214, yang berhubungan dengan delik yang melawan atau memaksa pejabat yang sedang menjalankan tugas yang menimbulkan luka. Demikian juga dengan Pasal 217 yaitu: perbuatan (perbuatan-perbuatan) yang menimbulkan kegaduhan di sidang pengadilan. Pasal ini telah diuji (judicial review) ke Mahkamah Konstitusi (MK), dalam pertimbangan Putusan No. 013-022/PUU-IV/2006, MK menyebutkan bahwa terkait pemberlakuan Pasal 207 KUHPidana, penuntutan hanya dilakukan atas dasar pengaduan dari penguasa. Jadi, apabila pemerintah yang dihina tersebut tidak mengadukan kasus penghinaan ini maka tidak dapat dipidana. Dengan demikian jelas bahwa sejak putusan MK ini maka rumusan delik Pasal 207 dirubah dari jenis delik biasa menjadi delik aduan. Sofian, A. (2019). Tafsir Delik Penghinaan Kepada Penguasa (Pasal 207 KUHP). https://businesslaw.binus.ac.id/2019/04/04/Tafsir-delik-penghinaan-kepada-penguasa-pasal-207-kuhp/, (Diakses Tanggal 24 November 2020).

${ }^{54}$ Hamzah, A. (2008). Op.Cit., h. 7.

55 Muladi, Arief, B. N. (1984). Teori-teori dan Kebijakan Pidana. Bandung: Alumni, h. 2-4.

${ }^{56}$ Berkaitan dengan RUU KUHPidana yang sedang dibahas, hukum pidana selalu mengandung dua unsur pokok yaitu: (1) Adanya norma yang dianggap mengikat (baik itu bersifat larangan atau suruhan/verbods en gebodsbepalingen), dan (2) Adanya sanksi (straf, punishment) atau penghargaan (reward) yang mengikutinya. Ibid.

${ }^{57}$ Cahyadi, E. (2007). Delik-Delik Keagamaan di Dalam RUU KUHP Indonesia. Cetakan Pertama. Jakarta: Kerjasama Aliansi Nasional Reformasi KUHP dan DRSP-USAID, h. LX-LXI.

58 Perbuatan tersebut merupakan kumpulan perbuatan dari begitu banyak perbuatan yang dinilai tercela dalam masyarakat. Selanjutnya pengaturan larangan perbuatan tercela yang merupakan delik, diatur juga dalam 
untuk melindungi masyarakat, ${ }^{59}$ adapun dalam kehidupan bermasyarakat dan bernegara, bertujuan untuk mendapatkan ketertiban, keamanan dan kesejahteraan sosial bagi masyarakat. ${ }^{60}$

Terkait dengan perbuatan tercela sebagai suatu kejahatan, dalam konsep hukum pidana ada dikenal dengan istilah mala per se atau mala in se, yang menganggap bahwa kesalahan tertentu merupakan kejahatan yang berkaitan dengan hati nurani dan dianggap tercela bukan karena peraturan perundang-undangan telah melarangnya, melainkan memang sudah dengan sendirinya salah. Sedangkan konsep mala in probohitia bertitik tolak dari pemikiran bahwa perbuatan dianggap tercela atau salah karena perundang-undangan telah melarangnya, sehingga disebut sebagai regulatory offenses. ${ }^{61}$

Oleh karenanya, antara perbuatan tercela yang dilarang atau strafbaar dan ancaman pidana atau strafmaat mempunyai hubungan sebab akibat (kausalitas). Jika dilihat dari hakekatnya, tindak pidana adalah perbuatan yang tercela (tercela karena dilarang oleh undangundang), sedangkan hukuman/pidana merupakan konkretisasi dari celaan. Bahkan larangan terhadap perbuatan yang termaktub dalam rumusan tindak pidana, timbul karena adanya ancaman penjatuhan pidana bagi yang melakukan perbuatan tercela. ${ }^{62}$ Ukuran untuk menilai perbuatan tercela tersebut adalah dengan adanya pelanggaran terhadap norma-norma atau kaedah-kaedah yang berakar pada nilai-nilai sosial-budaya, sebagai sistem tata kelakuan dan pedoman perbuatan masyarakat, yang dapat menyangkut norma keagamaan, kesusilaan dan hukum. Contohnya, tidak memenuhi sumpah/janji adalah suatu perbuatan tercela dalam pandangan masyarakat. ${ }^{63}$ Hal ini tentu saja senada dengan Soerjono Soekanto, yang menjelaskan bahwa kaedah hukum itu terhimpun dalam sistem hukum yang pada hakekatnya merupakan konkretisasi dari nilai-nilai sosial-budaya yang terwujud dan terbentuk dari kebudayaan suatu masyarakat. ${ }^{64}$

Terkait dengan nilai-nilai sosial-budaya, pengaturan delik kesusilaan sebagai perbuatan tercela dalam KUHPidana di Indonesia lebih menitikberatkan pada perlindungan terhadap korban tindakan asusila, berbanding terbalik dengan hukum Adat. ${ }^{65}$ Sedangkan delik agama

agama dan adat, yang memberikan larangan atau mencela perbuatan tersebut. Lihat mulai dari Pasal 104-488 KUHPidana (Buku II Kejahatan/misdrijven), Pasal 489-569 KUHPidana (Buku III Pelanggaran/overtredingen). Ismansyah \& Ermawati, B. (2012). Permasalahan Delik Zina Yang Terdapat Dalam Kitab Undang-Undang Hukum Pidana (KUHP). Jurnal Delicti: Jurnal Hukum Pidana dan Kriminologi, IX (1), h. 27.

59 Berikutnya pengaruh aliran modern dalam hukum pidana, memperkaya hukum pidana dengan sanksi yang disebut dengan tindakan (measure, maatregel), secara dogmatis pemidanaan (penghukuman) adalah sebagai pengimbalan atau pembalasan terhadap kesalahan-kesalahan si pelaku. Jerman, Nederland dan Indonesia adalah negara yang KUHPidana-nya menggunkan konsep double track system ini, artinya dalam KUHPidana digunakan dua jenis sanksi tersebut. Baca lebih lanjut Ersan, P., \& Erliyana, A. (2018). Kualifikasi Hukum Pidana Khusus Terhadap Tindak Pidana Pemilu/Pilkada (Tinjauan Hukum Administrasi Negara). Pakuan Law Review, 4(1), h. 67.

60 Menurut Romli, suatu kejahatan sering timbul disebabkan oleh kekuasaan negara, yang membentuk perundang-undangan, sehingga "kekuasaan menjadi penyebab dari kejahatan." Atmasasmita, R. (2010). Teori dan Kapita Selekta Kriminologi. Bandung: Refika Aditama, h. 3.

61 Fitroh Rohcahyanto berpandangan, hal ini akibat dari KUHPidana tidak memandang delik kesusilaan sebagai perbuatan tercela dan sangat buruk, melainkan sebagai perlindungan terhadap korban, sehingga menyebabkan pengaturan delik kesusilaan dalam KUHPidana berbeda dengan pengaturan kejahatan kesusilaan dalam hukum pidana Adat, kejahatan kesusilaan menurut beberapa daerah hukum Adat yang dipengaruhi normanorma agama, meletakkan delik kesusilaan tidak hanya untuk melindungi korban, tapi juga merupakan perbuatan yang sangat tercela dan buruk, sehingga patut mendapat hukuman. Rohcahyanto, F. (2018). Memperdagangkan Pengaruh (trading in influence) Sebagai Tindak Pidana Korupsi. Disertasi, Program Doktor Ilmu Hukum Fakultas Hukum Universitas Airlangga, h. 120.

${ }^{62}$ Waluyo, B. (2008). Pidana dan Pemidanaan. Edisi. 1. Cetakan. 3. Jakarta: Sinar Grafika, h. 1.

63 Pengaturan tentang perzinahan dalam KUHPidana disebut dengan istilah "gendak," yaitu: suatu perbuatan yang dilakukan oleh suami yang memiliki istri dengan isteri yang memiliki suami dan berlaku sebaliknya, sebagai delik aduan.

${ }^{64}$ Soekanto, S. (2015). Op.Cit., h. 43-44.

65 Sebagai contohnya dapat dilihat dari delik zina, dimana apabila yang melakukan kesusilaan tersebut adalah seorang laki-laki dan perempuan yang sudah sama-sama dewasa dan tidak terikat perkawinan, baik kedua-

386 |S A S I Vol. 27 No.3, Juli - September 2021 
dalam KHUPidana adalah mencakup perbuatan-perbuatan yang menurut hukum yang berlaku merupakan tindak pidana dan dilihat dari sudut pandang agama juga merupakan perbuatan tercela. ${ }^{66}$ Dasar yang digunakan untuk memasukkan delik agama dalam KUHPidana adalah Pancasila dan Pasal 29 UUD 1945, yang menegaskan negara berdasar Ketuhanan Yang Maha Esa. ${ }^{67}$

Merujuk dari penjelasan-penjelasan di atas, maka makna perbuatan tercela Presiden/Wakil Presiden dalam konsep hukum pidana adalah semua perbuatan yang bertentangan dengan nilai-nilai sosial budaya bangsa, perbuatan yang tidak baik, tidak bermoral, serta apa yang tidak diperbolehkan/dilarang dan apa yang seharusnya dilakukan, sebagaimana yang terdapat dalam KUHPidana. ${ }^{68}$ Adapun nilai-nilai agama, sosial budaya bangsa, kaedahkaedah kesusilaan yang terdapat di KUHPidana itu sudah terhimpun dalam Pancasila yang kemudian dijabarkan oleh UUD 1945 sebagai norma-norma hukum yang disepakati bersama. Penyimpangan perilaku Presiden dan/atau Wakil Presiden terhadap UUD 1945, yang menyebabkan terganggunya ketertiban dan ketentreraman kehidupan manusia dalam berbangsa dan bernegara adalah perbuatan tercela. ${ }^{69}$

Senapas dengan hal di atas, E.Y, Kanter dan S.R Sianturi menjelaskan bahwa tujuan hukum pidana pada umumnya adalah untuk melindungi kepentingan orang perseorangan (individu) atau hak-hak asasi manusia dan melindungi kepentingan-kepentingan masyarakat serta negara dari tindakan penguasa yang sewenang-wenang. ${ }^{70}$ Sebab itu, ketika seseorang (Presiden/Wakil Presiden) melakukan suatu perbuatan atau kebijakan haruslah terlebih dahulu mempertimbangkan apakah yang dilakukan sesuai dengan hukum dan moral kemanusiaan atau

duanya maupun salah satunya, maka hukum pidana tidak memandang sebagai kejahatan kesusilaan. Lihat buku Amriyanto, A. (2017). Menakar Nilai Agama dan Moral dalam Hukum Pidana Indonesia. Khairun Law Journal, 1(1), 62-72. h. 67-68.

66 Jazuli, A. (2017). Penyelesaian Konflik Penodaan Agama Dalam Perspektif Hukum Pidana Di Indonesia. Jurnal Penelitian Hukum De Jure, 17(3), 329-350. h. 337. Contohnya: korupsi dan tidak memenuhi sumpah/janji adalah perbuatan tercela, baik dari pandangan negara, agama, maupun adat budaya Indonesia. Baca juga Nurhayati, R, dkk. (2013). Pemahaman Tentang Korupsi (Suatu Tinjauan Yuridis dan Sosiologis terhadap Konsep Korupsi di Indonesia), Jakarta: Laporan Penelitian Kerjasama Antar Perguruan Tinggi (Pekerti) Universitas Terbuka, h. 31.

67 Ketuhanan Yang Maha Esa sebagai titik sentral dari kehidupan kenegaraan, maka delik "godslastering" sebagai "blasphemy" menjadi prioritas dalam delik Agama. Mudzakkir. (2010). Tindak Pidana Terhadap Agama Dalam Kitab Undang-Undang Pidana (KUHP) dan Undang-Undang Nomor 1/PNPS/1965 tentang Pencegahan Penyalahgunaan dan/atau Penodaan Agama (Kajian Terhadap Praktek Penegakan Hukum Dan Prospek Pengaturannya Dalam Hukum Positif Indonesia). Jakarta: Pusat Perencanaan Pembangunan Hukum Nasional Badan Pembinaan Hukum Nasional Kementerian Hukum Dan Hak Asasi Manusia, h. 9.

68 Sholehuddin, M. (2007). Sistem Sanksi Dalam Hukum Pidana: Ide Dasar Double Track System \& Implementasinya. Edisi. 1. Cetakan. 3. Jakarta: Raja Grafindo Persada, h. 55. Hukum pidana di Indonesia menganut asas legalitas, sesuai dengan Pasal 1 Ayat (1) KUHPidana, yang menegaskan bahwa "tiada suatu perbuatan dapat dipidana kecuali atas kekuatan aturan pidana dalam perundang-undangan yang telah ada sebelum perbuatan dilakukan." Begitu juga dalam konsep RUU KUHPidana Tahun 2019, dalam Pasal 1 Ayat (1) juga menegaskan bahwa "tidak ada satu perbuatan pun yang dapat dikenai sanksi pidana dan/atau tindakan kecuali atas kekuatan peraturan pidana dalam peraturan perundang-undangan yang telah ada sebelum perbuatan dilakukan." Kemudian Pasal 2 Ayat (1), merumuskan pula, bahwa "ketentuan sebagaimana dimaksud dalam Pasal 1 ayat (1) tidak mengurangi berlakunya hukum yang hidup dalam masyarakat yang menentukan bahwa seseorang patut dipidana walaupun perbuatan tersebut tidak diatur dalam undang-undang itu; Ayat (2) Hukum yang hidup dalam masyarakat sebagaimana dimaksud pada Ayat (1) berlaku dalam tempat itu hidup dan sepanjang tidak diatur dalam Undang-Undang ini dan sesuai dengan nilai-nilai yang terkandung dalam Pancasila, Undang-Undang Dasar Negara Republik Indonesia Tahun 1945, hak asasi manusia, dan asas hukum umum yang diakui oleh masyarakat beradab. Dengan memperhatikan konsepsi asas legalitas RUU KUHPidana tersebut, maka menurut Wijaksana bertolak pada keseimbangan antara asas legalitas formal dan asas legalitas materil. Baca juga Wijaksana, M. M. S. (2020). Perkembangan Formulasi Asas Legalitas Dalam Sistem Pemidanaan Di Indonesia (Studi Komparatif Antara KUHP/WVS \& RUU KUHP 2019). Jurnal RechtsVinding, h. 5.

69 Supanto, S. (2004). Pelecehan Seksual Sebagai Kekerasan Gender: Antisipasi Hukum Pidana. Mimbar: Jurnal Sosial dan Pembangunan, 20(3), 288-310. h. 296.

70 Istiqamah, D. T. (2018). Analisis Nilai Keadilan Restoratif Pada Penerapan Hukum Adat Di Indonesia. Veritas et Justitia, 4(1), 201-226. h. 202.

387 ISASI Vol. 27 No.3, Juli - September 2021 
tidak. $^{71}$ Pendapat senada disampaikan E.Ph. Sutorious, dengan mengatakan bahwa perbuatan tercela (sebagai kesalahan) adalah melakukan sesuatu yang seharusnya tidak dilakukan, dan tidak melakukan sesuatu yang seharusnya dilakukan. ${ }^{72}$

Selanjutnya secara formil perbuatan tercela Presiden/Wakil Presiden adalah disebabkan karena UUD 1945 melarang atau memerintahkan perbuatan tersebut yang disertai dengan ancaman sanksi. Adapun perbuatan tercela secara materil adalah karena perbuatan tersebut bertentangan atau tidak sesuai dengan nilai-nilai keberadaban masyarakat dan sanksi yang diberikan bukanlah sanksi pidana, tetapi sanksi yang terdapat dalam kaidah-kaidah UUD 1945, hal yang demikian adalah sesuai dengan Pancasila utamanya asas kemanusian yang adil dan beradab yang merupakan sendi dalam kehidupan berbangsa dan bernegara. ${ }^{73}$

Beranjak dari pemaparan yang telah disampaikan, maka didapat pengertian, sebagai berikut: Pertama, bahwa semua perbuatan yang melanggar delik hukum pidana adalah perbuatan tercela, dan sanksinya adalah pidana sesuai dengan KUHPidana, sehingga perbuatan tercela yang sudah diatur secara formal dalam KUHPidana bukanlah makna perbuatan tercela yang dimaksud dalam Pasal 7A UUD 1945, sebab sudah ditentukan limitatif perbuatan pidana yang dapat memberhentikan Presiden/Wakil Presiden dalam masa jabatannya, yakni: korupsi, penyuapan, dan tindak pidana berat lainnya; Kedua, perbuatan tercela Presiden/Wakil Presiden sebagaimana yang termaktub dalam Pasal 7A UUD 1945 adalah perbuatan pelanggaran terhadap UUD 1945 sebagai rujukan kaedah hukum (hukum pidana) yang disepakati bersama, disamping itu konstruksi perbuatan tercela dalam Pasal 7A UUD 1945 adalah campuran antara perbuatan tercela sebagai pelanggaran hukum dengan moral/etika, dengan demikian UUD 1945 adalah sebagai sumber rule of ethic bagi Presiden/Wakil Presiden. ${ }^{74}$

Terkait dengan tindak pidana berat lainnya, MK telah mendefeniskan frasa tersebut, seperti terdapat dalam Pasal 10 Ayat (3) point (c) UU No. 24 Tahun 2003 tentang MK, yang menjelaskan bahwa: tindak pidana berat lainnya adalah tindak pidana yang diancam dengan pidana penjara 5 (lima) tahun atau lebih. Adapun tindak pidana yang diancam penjara 5 tahun atau lebih dalam KUHPidana dan tergolong khusus diantaranya: (1) Pembunuhan (diancam pidana 15 tahun), perampasan kemerdekaan (diancam pidana 8 tahun); (2) Kejahatan penerbangan yang bervariasi paling ringan 6 (enam) tahun dan paling berat diancam dengan pidana penjara 15 (lima belas) tahun; (3) Tindak pidana teroriseme diancam dengan pidana mati; (4) Dalam UU Informasi dan Transaksi Elektronik, ${ }^{75}$ tindak pidana melanggar kesusilaan diperberat pidananya selama 6 (enam) tahun; (4) Tindak pidana kekerasan dalam rumah tangga

71 Baca lebih lengkap Maramis, F. (2016). Op.Cit., h. 165. Dalam konsep hukum pidana juga ada dikenal dengan tindak pidana khusus, yang berarti bahwa perlakuan terhadap subjek hukum; hukum acara, acaman dan pengaturannya tergolong khusus, misalnya korupsi dan narkotika. Kejahatan mengenai perilaku tidak melaksanakan amanah serta tidak memenuhi kewajiban dan hak-hak negara (oleh Presiden/Wakil Presiden, misalnya); kejahatan terhadap ketertiban umum adalah juga mempunyai nilai kekhususan, meskipun sebahagian kejahatan-kejahatan tersebut sudah masuk dalm KUHPidana. Baca juga Siahaan, M. 2016. Pembaruan Hukum Pidana Indonesia. Jakarta: Gramedia, h. 10.

72 Kesalahan memandang hubungan antara perbuatan tercela dan pelakunya, artinya perbuatan tercela tersebut sesungguhnya merupakan perbuatannya. Amrani, H, Ali, M. (2015). Sistem Pertangungjawaban Pidana: Perkembangan dan Penerapan. Edisi. 1. Cetakan. 1. Jakarta: Raja Grafindo Persada, h. 24.

73 Farid, Z. A. (2007). Hukum Pidana 1. Edisi. 1. Cetakan. 2. Jakarta: Sinar Grafika, h. 242. Adapun Barda Nawawi Arif, mengemukakan bahwa pertanggungjawaban tindak pidana dititikberatkan kepada adanya perbuatan yang tercela secara objektif maupun tercela secara subjektf. Makna pencelaan secara objektif, ukurannya adalah adanya norma larangan maupun norma kaharusan dalam UU, perbuatan, kegiatan atau aktivitas memang patut dicela. Pencelaan secara subjektif, diarahkan kepada pelakunya bahwa dia patut di pidana. Asas yang mendasari pertanggungjawaban pidana merupakan asas kesalahan geen straf zonder schuld atau tiada pidana tanpa kesalahan. Arief, B. N. (2010). Bunga Rampai Kebijakan Hukum Pidana: (Perkembangan Penyusunan Konsep KUHP Baru), Edisi Pertama. Cetakan ke-2. Jakarta: Kencana, h. 89-95.

74 Said, H. M. (2021). Menggagas Peradilan Etik Penyelenggara Negara Di Indonesia. SASI, 27(1), 24-37. h. 33 .

75 Undang-Undang No. 11 Tahun 2008 tentang Informasi dan Transaksi Elektronik.

388 |S A S I Vol. 27 No.3, Juli - September 2021 
yang diancam dengan pidana penjara menjadi 10 (sepuluh) tahun penjara; (5) Tindak pidana korupsi, perbuatan memperkaya diri sendiri, orang lain atau korporasi yang dapat merugikan keuangan negara" yang semula diancam dengan pidana penjara 20 (dua puluh) tahun, diperberat menjadi jenis acaman pidana sampai pidana mati. ${ }^{76}$

Istilah tindak pidana juga sering disebutkan dengan perbuatan pidana, ${ }^{77}$ ada juga yang menyebutnya dengan peristiwa pidana yang berasal dari hukum pidana Belanda, yaitu: stafbaar feit dalam kata Latin disebut delict atau delectum. ${ }^{78}$ Tindak pidana terbagi atas tindak pidana umum, tindak pidana khusus, tindak pidana materil dan tindak pidana formil. ${ }^{79}$ Adapun pembenaran penjatuhan sanksi pidana, didasarkan pada: Pertama, teori absolut/pembalasan, dimana sanksi pidana diberikan karena pelaku telah melakukan tindak pidana; Kedua, teori relatif/doel theorien, yang menjelasakan bahwa dasar pemidanaan itu adalah alat untuk menegakkan hukum di masyarakat; Ketiga, teori gabungan/vereniging theorien, adalah pemidanaan yang berkarakter pembalasan dan pada sisi ide atau tujuannya adalah untuk perubahan prilaku pelaku kejahatan untuk dapat hidup lebih baik di tengah-tengah masyarakat. ${ }^{80}$

Hukum pidana tunduk pada asas legalitas, yakni: "vom psychologischen zwang," dengan menekankan agar dalam menentukan perbuatan-perbuatan yang dilarang UU Pidana, bukan saja tentang jenis perbuatan yang harus dituliskan dengan jelas, tetapi juga tentang pidana yang diancamkan. ${ }^{81}$ Dalam tradisi civil law system, ada empat aspek asas legalitas yang diterapkan secara ketat, yaitu: (1), peraturan perundang-undangan (law); (2) Non-retroaktif (retroactivity); (3) lex certa; dan (4) analogi. ${ }^{82}$

\section{Makna Perbuatan Tercela Dalam Kajian Hukum Pidana}

Andi Hamzah membuka ruang penggunaan analogi dalam hukum pidana, yaitu: Pertama, gesetz analogi adalah analogi terhadap perbuatan yang sama sekali tidak terdapat dalam

76 Huda, C. (2011). Pola Pemberatan Pidana dalam Hukum Pidana Khusus. Jurnal Hukum IUS QUIA IUSTUM, 18(4), 508-524. h. 119.

77 Simons mendefensikan hukum Pidana sebagai berikut: Pertama, hukum Pidana materil, yang mengandung petunjuk-petunjuk dan uraian tentang delict, peraturan-peraturan tentang syarat-syarat serta hal-hal yang dapat mempidanakan seseorang (strafbaarfeit), penunjukan tentang seorang yang dapat dipidana serta ketentuan tentang pidananya, hukum pidana materil juga mengatur tentang menetapkan siapa dan bagaimana orang dipidana; Kedua, hukum pidana formil adalah hukum yang mengatur tentang tata cara negara dengan perantaraan para pejabatnya menggunakan haknya untuk memidanakan. Baca lebih lengkap buku Hamzah, A. (2008). AsasAsas Hukum Pidana. Edisi Revisi. Jakarta: Rineka Cipta, h. 2-3. Criminal justice system di Indonesia terdiri atas komponen Kepolisian, Kejaksaan, Pengadilan Negeri dan Lembaga Pemasyarakatan sebagai aparat penegak hukum (tidak ada Mahkamah Konstitusi). Lihat juga Atmasasmita, R. (1996). Sistim Peradilan Pidana. Bandung: Binacipta, h. 32.

78 Baca lebih lanjut buku Suhartoyo. (2019). Argumen Pembalikan Beban Pembuktian Sebagai Metode Prioritas dalam Pemberantasan Tindak Pidana Korupsi dan Tindak Pidana Pencucian Uang. Depok: Raja Grafindo Persada, h. 19-28.

79 Di Indonesia tindak pidana umum adalah semua delik yang terdapat dalam KUHPidana beserta semua perundang-undangan yang mengubah dan menambah KUHPidana. Sedangkan pidana khusus adalah semua perundang-undangan diluar KUHPidana beserta perundang-undangan pelengkapnya, baik perundang-undangan pidana maupun yang bukan pidana, tetapi bersanksi pidana (perundang-undangan khusus). Ibid.

80 Atmadja, I. G. D., Budiartha, I. P. N. (2018). Teori-Teori Hukum. Malang: Setara Press, h. 175-177.

81 Teori tentang asas legalitas ini disampaikan Von Feurbach. Baca buku Moeljatno. (2002). Op.Cit.

82 Menurut Roelof H. Haveman, keempat aspek asas legalitas tersebut dapat dijelaskan sebagai berikut: Pertama, Lex Scripta adalah pemidanaan harus didasarkan pada undang-undang; Kedua, Lex Certa adalah jelas dan rinci dalam kaitannya dengan hukum yang tertulis, pembuat undang-undang (legislatif) harus merumuskan secara jelas dan rinci mengenai perbuatan yang disebut dengan tindak pidana (kejahatan, crimes); Ketiga, analogi artinya memperluas berlakunya suatu peraturan dengan mengabstraksikannya menjadi aturan hukum yang menjadi dasar dari peraturan itu (ratio legis) dan kemudian menerapkan aturan yang bersifat umum ini kepada perbuatan konkrit yang tidak diatur dalam undang-undang; Keempat, Non-retroaktif adalah bahwa ketentuan peraturan perundang-undangan yang merumuskan tindak pidana tidak dapat diberlakukan secara surut. Baca lebih lanjut Iksan, M. 2017. Op.Cit., h. 8-10.

$$
389 \text { |SASI Vol. } 27 \text { No.3, Juli- September } 2021
$$


ketentuan pidana; dan Kedua, recht analogi adalah analogi terhadap perbuatan yang mempunyai kemiripan dengan perbuatan yang dilarang dalam ketentuan hukum pidana. ${ }^{83}$ Jika dikaitkan dengan perbuatan tercela, Remmelink menjelsakan, bahwa untuk dapat dipidananya suatu perbuatan yang tercela harus ada ketentuan dalam undang-undang pidana yang merumuskan suatu perbuatan yang menjadi tindak pidana dan memberikan sanksi terhadap perbuatan tercela tersebut. ${ }^{84}$

Di Indonesia, asas legalitas ini dapat diterapkan secara tidak kaku, dengan menjadikan hukum Adat atau hukum yang hidup di masyarakat (the living law) menjadi sumber hukum pidana, selain KUHPidana. ${ }^{85}$ Sebab di Indonesia suatu tindak pidana dapat dikategorikan pada perbuatan tercela dan perbuatan melawan hukum. ${ }^{86}$ Sebagai salah satu unsur mutlak dari suatu delik, perbuatan melawan hukum dicantumkan dalam Pasal 1 ayat (1) KUHPidana, penegasan ini merupakan asas legalitas formal (nulla poena sine lege), yang bertujuan untuk memberikan kepastian hukum. ${ }^{87}$ Dengan demikian, apabila terdapat perbuatan (Presiden/Wakil Presdien) yang menurut masyarakat tercela sehingga patut untuk dipidana, maka perbuatan tersebut tidak dapat dipidana apabila ternyata belum ada perundang-undangan yang merumuskan perbuatan tercela tersebut sebagai delik. ${ }^{88}$

\section{Asas Legalitas Perbuatan Tercela Dalam Perspektif Konstitusi (UUD 1945)}

Terkait asas legalitas materil dan asas legalitas formal, di Indonesia kedua asas tersebut dapat berjalan beriringan, sebab nilai-nilai hukum Adat atau hukum yang hidup di masyarakat itu sendiri secara legal formal sudah menjadi sumber dari segala sumber hukum di Indonesia, melalui Pancasila sebagai "roh" dari UUD 1945. ${ }^{89}$ Pendapat ini sejalan dengan politik hukum pembentukan sistem hukum pidana dalam Rancangan Undang-Undang Hukum Pidana (RUUKUHPidana) di Indonesia, yang beradab dan disesuaikan dengan budaya bangsa Indonesia yang didasarkan Pancasila dan UUD $1945 .{ }^{90}$ Dengan perspektif demikian, maka

83 Pendapat Andi Hamzah ini didasarkan pada para pakar, seperti: Hazewinkel-Suringa, Roland Freisler, Vos, Pompe, Paul Scholten, Utrecht, Taverne dan Wijers. Lihat dalam buku Hamzah, A. (2008). Op.Cit., h. 44-54.

84 Remmelink, J. (2003). Hukum Pidana: Komentar Atas Pasal-pasal Terpenting dari Kitab UndangUndang Hukum Pidana Belanda dan Padanannya dalam Kitab Undang-undang Hukum Pidana Indonesia. Jakarta: Gramedia, h. 599.

85 Asas subsidiaritas adalah asas UU Pidana harus diartikan seluas-luasnya dan tidak hanya mengenai pidananya saja, tetapi mengenai segala sesuatunya dari peraturan itu yang mempunyai pengaruh terhadap penilaian tindak pidana, penentuannya harus dilakukan in concreto dan tidak in abstracto, ketentuan yang demikian terdapat dalam: (1) UU No. 1 /Drt/1951 tentang Tata Susunan Lembaga Peradilan; (2) UU No. 19 Tahun 1964 tentang Kekuasaan Kehakiman; UU No. 14 Tahun 1970 tentang Ketentuan Pokok-pokok Kekuasaan Kehakiman; UU No. 35 Tahun 1999 tentang Perubahan terhadap UU No. 14 Tahun 1970; UU No. 4 Tahun 2004 tentang Kekuasaan Kehakiman; (3) Pasal 24 UUD 1945. Iksan, M. (2017). Op.Cit., h. 16.

${ }^{86}$ Pohan, A, dkk. (2012). Hukum Pidana Dalam Perspektif. Edisi Pertama. Denpasar: Pustaka Larasan, h. 115- 125.

87 Melawan hukum dalam hal ini diartikan sebagai bertentangan dengan perundang-undangan (legalitas formal), yang dianut dari Code Penal Perancis. Adapun legalitas materil adalah merupakan dasar dalam memberlakukan hukum yang hidup di masyarakat, sehingga penentu perbuatan tercela sebagai perbuatan pidana harus didasarkan pada kondisi konkrit masyarakat. Supusesa, R. (2012). Op. Cit. , h. 51.

88 Nurdin, F. S. (2016). Rekonstruksi Asas Legalitas Dalam Hukum Pidana Berdasarkan Prinsip Keadilan, Refleksi Hukum: Jurnal Ilmu Hukum, 1(1), h. 8. Asas legalitas (principle of legality) biasa dikenal dalam bahasa Latin dengan nullum delictum nulla poena sine praevia lege (tidak ada delik, tidak ada pidana tanpa peraturan lebih dahulu), adagium ini berasal dari Von Feuerbach. Moeljatno (2002). Op.Cit., h. 23.

89 Delik; Delict; Delikt; Strafbaar Feit; Offence, Crminal act adalah istilah yang umum digunakan dalam peraturan perundang-undangan di Indonesia yang dimaknai sebagai "tindak pidana," menurut Andi Hamzah istilah delik juga dimaknai dengan tanpa berbuat atau tidak bertindak yang disebut pengabaian, dalam bahasa Belanda adalah nalaten dan bahasa Inggris negligence atau perbuatan yang diharuskan. Hamzah A. (2008). Terminologi Hukum Pidana, Edisi Pertama. Cetakan Pertama. Jakarta: Sinar Grafika, h. 47. Jadi ketika Presiden/Wakil Presiden mengabaikan atau tidak berbuat sesuatu yang sudah diperintahkan (diamanahkan) oleh konstitusi (UUD 1945) dan peraturan perundang-undangan lainnya, maka Presiden/Wakil Presiden dapat dimaknai telah melakukan delik.

90 Tujuan Pembentuk RUU KUHPidana adalah dekolonisasi dan konsolidasi. Dekolonisasi mengandung makna melakukan formulasi ulang atau reformulasi terhadap berbagai kejahatan yang diatur, sedangkan

390 | S A S I Vol. 27 No.3, Juli - September 2021 
seseorang Presiden/Wakil Presiden di Indonesia dapat saja diadili dan dijatuhi pidana tanpa harus melanggar ketentuan hukum pidana yang telah ada, tetapi sudah cukup apabila perbuatan tersebut dipandang sebagai perbuatan yang tercela oleh masyarakat, dengan batu ujinya adalah nilai-nilai yang terkandung dalam Pancasila dan UUD 1945. ${ }^{91}$

Sebab itu, pedoman untuk menentukan sumber hukum materil yang dapat dijadikan sebagai bahan hukum (sumber legalitas) tersebut adalah sepanjang sesuai dengan nilai-nilai Pancasila dan/atau UUD 1945. ${ }^{92}$ Asas berikutnya terkait dengan perbuatan tercela adalah pertanggungjawaban, yakni: siapa yang berbuat, maka dia yang mempertangungjawabankan perbuatannya, suatu perbuatan tercela sebagai tindak pidana dan bentuk pertanggunganjawabnya harus memperoleh pengaturan yang jelas dalam undang-undang. ${ }^{93}$ Berikutanya asas yang fundamental dalam hukum pidana adalah asas kesalahan, seseorang dikatakan bersalah apabila ia dapat dicela dari penilaian moral, sebab ia dianggap semestinya dapat berbuat patut, sedang yang dimaksud dengan kesalahan ialah keadaan jiwa seseorang yang melakukan perbuatan itu dalam hubungannya dengan perbuatannya, dan hubungan itu sedemikian rupa, shingga ia dapat dicela atas perbuatannya, demikian pula apabila Presiden/Wakil Presiden dicela atas perbuatannya, maka ia dapat di hukum. ${ }^{94}$ Karenanya, ilmu hukum pidana menilai apakah asas-asas hukum pidana telah sesuai dengan tata susila dan jiwa bangsa, serta menilai apakah peraturan-peraturan yang berlaku sejalan dengan asas-asas yang telah ada. ${ }^{95}$

konsolidasi adalah menghimpun dan mensistematisasi berbagai tindak pidana, baik yang ada dalam KUHPidana maupun di luar KUHPidana dalam suatu kitab undang-undang, namun demikian, rekodifikasi dan konsolidasi dalam RUUHPidana tetap memberi peluang tumbuh dan berkembangnya kejahatan dimensi baru di kemudian hari, dengan tetap mengacu kepada asas-asas yang terkandung dalam Buku Kesatu KUHPidana. Lihat Imran, Hidayati, F. R. (2019). Memperkuat Peradaban Hukum dan Ketatanegaraan Indonesia. Cetakan Pertama. Jakarta: Sekretariat Jenderal Komisi Yudisial Republik Indonesia, h. 250-251.

91 Namun, ajaran sifat melawan hukum materil dalam penjelasan Pasal 2 ayat (1) UU No. 31 Tahun 1999 tentang Pemberantasan Tindak Pidana Korupsi telah dinyatakan tidak mengikat dan bertentangan dengan UUD 1945, berdasarkan Putusan MK RI No. 003/PUU-IV/2006 tentang Pengujian UU No. 31 tahun 1999 tentang Pemberantasan Tindak Pidana Korupsi sebagaimana telah diubah dengan UU No. 20 Tahun 2001. Putusan MK tersebut menyatakan: bahwa sepanjang frasa yang berbunyi "secara melawan hukum" dalam Pasal ini mencakup perbuatan melawan hukum dalam arti formil maupun dalam arti materil, yakni meskipun perbuatan tersebut tidak diatur dalam peraturan perundang-undangan, namun apabila perbuatan tersebut dianggap tercela karena tidak sesuai dengan rasa keadilan atau norma-norma kehidupan sosial dalam masyarakat, maka perbuatan tersebut dapat dipidana, bertentangan dengan UUD 1945. Selain itu juga diputus bahwa: Penjelasan Pasal 2 ayat (1) UndangUndang Republik Indonesia Nomor 31 Tahun 1999 tentang Pemberantasan Tindak Pidana Korupsi tidak mempunyai kekuatan hukum mengikat. Sebab hal tersebut sangat bertentangan dengan KUHPidana yang menjunjung tinggi asas legalitas yang merupakan asas yang sangat fundamental dalam hukum pidana. Sudirman, A. (2009). Eksistensi Hukum Dan Hukum Pidana Dalam Dinamika Sosial Suatu Kajian Teori Dan Praktik Di Indonesia. Semarang: BP UNDIP, h. 53-54.

92 Argumentasi ini berdasar dari doktrin "the general principle of law recognized by the community of nations" yang terdapat dalam Pasal 15 Ayat (2) International Covenant on Civil and Political Right (ICCPR), yang menegaskan bahwa suatu perbuatan dinyatakan sebagai tindak pidana adalah perbuatan yang dilarang dan diancam pidana oleh peraturan perundang-undangan, yang harus juga bersifat melawan hukum atau bertentangan dengan hukum yang hidup dalam masyarakat, hal demikian ini adalah baru dalam konsep hukum pidana di Indonesia, sebab ketentuan umum seperti itu tidak ada dalam KUHPidana. Lihat lebih jauh dalam Badan Pembinaan Hukum Nasional. (2015). Naskah Akademik Rancangan Undang-Undang Tentang Kitab Undang-Undang Hukum Pidana (KUHP). Jakarta: Kementerian Hukum dan Hak Asasi Manusia Republik Indonesia, h. 28-29.

93 Adapun yang dimaksud dengan pertanggunganjawaban pidana adalah diteruskannya perbuatan tercela tersebut yang secara objektif ada pada tindak pidana berdasarkan ketentuan hukum yang berlaku, dan secara subjektif kepada pembuat yang memenuhi syarat dalam KUHPidana, untuk dapat dikenai pidana karena perbuatannya, maka timbullah pertanggungjawaban pidana. Ibid. Lihat juga Jafar, W. A. (2016). Analisis Asas Hukum Pidana Islam Dan Asas Hukum Pidana Di Indonesia. Al-Istinbath: Jurnal Hukum Islam, 1(1), 25-44. h. 31.

94 Ibid.

95 Baca lebih lengkap buku Mertha I. K, dkk. (2016). Buku Ajar Hukum Pidana, Denpasar: Fakultas Hukum Universitas Udayana, h. 28.

391 |S A S I Vol. 27 No.3, Juli - September 2021 


\section{Unsur-Unsur Perbuatan Tercela Menurut Konsep Hukum Pidana}

Secara luas, unsur-unsur strafbaar feit, terdiri dari: (1) orang sebagai pelaku; (2) perbuatan bersifat melawan hukum; (3) kesalahan dan pidana. Adapun dalam arti sempit adalah unsur-unsur dari setiap tindak pidana sebagai prilaku menyimpang baik yang di atur dalam KUHPidana ataupun di luar KUHPidana. ${ }^{96}$ Mengenai unsur-unsur delik, para ahli hukum pidana sepakat membagi dua jenis, yaitu: unsur objektif dan unsur subjektif. Unsur objektif adalah perbuatan pidana yang mengacu pada asas legalitas (terdapat dalam KUHPidana), adapun unsur subjektif terletak pada pelaku yang mengacu pada asas culvabilitas/kesalahan, kedua unsur ini adalah penentu untuk dapat atau tidaknya seseorang dipidana. ${ }^{97}$

Argumentasi ini sejalan dengan keseimbangan asas legalitas formal dan materil. Dengan demikian, tindak pidana diarikan sebagai: Pertama, perbuatan melakukan atau tidak melakukan sesuatu yang oleh peraturan perundang-undangan dinyatakan sebagai perbuatan yang dilarang dan diancam pidana; Kedua, suatu tindak pidana harus bersifat melawan hukum atau bertentangan dengan hukum yang hidup dalam masyarakat; Ketiga, setiap tindak pidana selalu dipandang bersifat melawan hukum, kecuali ada alasan pembenar. ${ }^{98}$ Intinya tindak pidana itu memiliki empat unsur, yakni: (1) Perturan; (2) Perbuatan; (3) Pelaku; dan (4) Pidana (sanksi/hukuman). ${ }^{99}$ Pendapat senada disampaikan Moeljatno, R.Tresna, Vos Adami, ${ }^{100}$ dan Lamintang. ${ }^{101}$

Adapun yang terkait dengan unsur melawan hukum dalam konsep hukum pidana mempunyai dua sifat, yakni: sifat melawan hukum formil dan materil. Sifat melawan hukum formal adalah perbuatan yang bertentangan dengan hukum yang berisikan norma perintah dan larangan, sedangkan sifat melawan hukum materil adalah pelanggaran terhadap kepentingankepentingan sosial yang dilindungi oleh norma-norma hukum perorangan atau masyarakat, termasuk kerusakan atau membahayakan suatu kepentingan umum. ${ }^{102}$ Di Indonesia disepakati bahwa the living law adalah sumber hukum positif, baik melalui legislasi maupun putusan hakim, Mochtar Kusumaatmadja, mengatakan: "selain hukum, kehidupan manusia dalam masyarakat berpedoman pada moral, yang diatur oleh agama, kaidah-kaidah susila, kesopanan, adat kebiasaan dan kaidah-kaidah sosial lainnya."103

Hubungan hukum tidak tertulis dan hukum tertulis tersebut adalah sebagai penilai

96 Untuk menentukan unsur-unsur yang seharusnya melekat dalam setiap tindak pidana, para sarjana berbeda pendapat, inti perbedaan tersebut yaitu: (1) Paham monistis, menyatukan semua unsur yang ada untuk menetukan adanya tindak pidana, sedangkan paham dualistis, memisahkan unsur yang dikatagorikan sebagai perbuatan pidana dengan kesalahan. Ibid., h. 101-102.

97 Remmelink, J. (2003). Op.Cit., h. 61.

98 Lihat Badan Pembinaan Hukum Nasional. (2015). Op.Cit.

99 Maramis, F. (2016). Hukum Pidana Umum dan Tertulis Indonesia. Edisi ke-1. Cetakan Ke-3. Depok: Raja Grafindo Persada, h. 13.

100 Pendapat Jonkers sedikit berbeda dengan menyatakan unsur perbuatan pidana (tercela) terdiri dari: perbuatan (yang); melawan hukum (yang berhubungan dengan); kesalahan (yang dilakukan oleh orang yang dapat); dipertanggungjawabkan. Chazawi, A. (2011). Pelajaran Pidana Bagian 1. Edisi ke-1. Cetakan ke-6. Jakarta: Raja Grafindo Persada, h. 81.

101 Unsur objektif adalah unsur yang berhubungan dengan keadaan-keadaan dari si pelaku, meliputi: (1) Perbuatan manusia, yang terbagi atas perbutan yang bersifat positif dan bersifat negatif yang menyebabkan suatu pelanggaran pidana; (2) Akibat perbuatan manusia, maksudnya adalah akibat yang terdiri atas merusaknya atau membahayakan kepentingan-kepentingan hukum, yang menurut norma hukum pidana mendapakan sanksi; (3) Keadaan-keadaan di sekitar perbuatan itu; (4) Sifat melawan hukum dan sifat dapat dipidana. Sofyan, A, Azisa, N. (2016). Op.Cit., h. 99-102.

102 Sesungguhnya dalam KUHPidana tidak secara tegas dirumuskan, namun dapat ditemukan dalam beberapa pengertian antara lain Pasal 167, Pasal 522 mengandung makna "bertentangan dengan hukum," Pasal 406 dengan rumusan "tanpa hak sendiri," kemudian Pasal 333 dengan norma yang menyebutkan "bertentangan dengan hukum objektif.” Baca lebih lengkap Sudharmawatiningsih. (2007). Op. Cit, h. 11.

103 Kusumaatmadja, M. (2006). Konsep-Konsep Hukum Dalam Pembangunan. Cetakan ke-2. Bandung: Alumni, h. 4.

$$
392 \text { |S ASI Vol. } 27 \text { No.3, Juli - September } 2021
$$


terhadap suatu perbuatan tercela, yang dapat menentukan apakah yang harus dilakukan seseorang (Presiden/Wakil Presiden) dan apakah yang harus dihindarinya. Namun, menurut Schaffmeister, Keijzer, dan Sutorius, perbuatan tercela tersebut harus diatur dalam hukum tertulis, sebab tidak dapat dijatuhkan pidana karena suatu perbuatan yang tidak termasuk dalam rumusan delik, dengan memenuhi dua unsur, yaitu: perbuatan itu bersifat melawan hukum dan dapat dicela. ${ }^{104}$

Selanjutnya sifat subjektif dari hukum pidana adalah adanya kesalahan (schuld), yakni: mengenai keadaan atau gambaran batin orang sebelum atau pada saat memulai perbuatan tercela, karena itu unsur ini selalu melekat pada diri pelaku. Hanya orang yang dapat diminta pertanggungjawaban saja yang dapat dipersalahkan, orang yang kurang sempurna akalnya atau sakit jiwa (gila) tidak dapat diminta pertanggung jawaban atas perbuatannya, karena itu tidak dapat dipersalahkan. ${ }^{105}$ Sebab pertanggungjawaban pidana adalah diteruskannya celaan yang objektif ada pada tindak pidana dan secara subjektif kepada seseorang yang memenuhi syarat untuk dapat dijatuhi pidana karena perbuatannya. ${ }^{106}$

Beranjak dari pemaparan yang telah disampaikan, jika dihubungkan dengan unsur-unsur perbuatan tercela yang terdapat pada Pasal 7A UUD 1945, maka diperoleh pengertian, Pertama, unsur-unsur perbuatan tercela Presiden/Wakil Presiden dalam Pasal 7A UUD 1945, terdiri dari: (1) Perturan, dalam Pasal 7A UUD 1945; (2) Perbuatan, pelanggaran sumpah/janji jabatan; (3) Pelaku, Presiden/Wakil Presiden; dan (4) Sanksi/hukuman, dimakzulkan; Kedua, unsur objektif perbuatan tercela Presiden/Wakil Presiden, sebagai berikut: (1) Perbuatan Presiden/Wakil Presiden yang tidak mau memenuhi kewajiban hukum sumpah/janji jabatannya dan perbuatan yang bertentangan dengan kewajiban hukum sumpah/janji jabatannya; (2) Akibat Presiden/Wakil Presiden tidak memenuhi sumpah/janji, menyebabkan tidak terpenuhinya dan/atau hilangnya hak-hak konstitusional rakyat, sehingga membahayakan kepentingankepentingan hukum; (3) Keadaan-keadaan di sekitar perbuatan tercela itu adalah Presiden/Wakil Presiden seharusnya mampu dan/atau dapat memenuhi sumpah/janji jabatanya, namun ia tidak mau melakukannya; (4) Sifat melawan hukumnya adalah melanggar Pasal 9 Ayat (1) UUD 1945 tentang sumpah/janji jabatan Presiden/Wakil Presiden; ${ }^{107}$

104 Andi Sofyan, A, Azisa, N. (2016). Op.Cit.

105 Pembuat undang-undang menganggap, bahwa orang pada umumnya sehat, sehingga bila ia melakukan perbuatan tercela (melanggar norma pidana) dapat diminta pertanggungjawaban. Barulah jika timbul keraguraguan tentang keadaan jika seseorang, maka diadakan penyelidikan lebih lanjut. Tentang tanggung jawab orang ini diatur dalam Pasal 44 KUHPidana yang menegaskan, "barang siapa melakukan suatu perbuatan yang tidak dapat dipertanggung jawabkan kepadanya karena kurang sempurna akalnya atau karena sakit berobah akalnya tidak boleh dipidana." Oleh karena itu, suatu asas pokok dari hukum pidana adalah "tidak ada pidana tanpa kesalahan." Kesalaahan dalam arti hukum pidana mengandung beban pertanggungjawaban pidana, yang terdiri atas kesengajaan (dolus) dan kelalaian (culpa). Sebagai contoh suatu kesengajaan terdapat pada Pasal 338 KUHPidana tentang pembunuhan, sedangkan kelalaian dapat dirumuskan dalam Pasal 359 KUHPidana, yaitu menyebabkan mati. Ibid.

106 Maroni. (2015). Pengantar Hukum Pidana Administrasi. Bandar Lampung: Anugrah Utama Raharja, h. 88.

107 Terkait dengan unsur sifat melawan hukum (wederrechtelijkheid) suatu tindak pidana yang bersifat objektif, terdiri dari dua jenis sifat, yaitu: sifat melawan hukum formal (formale wederrechtelijkheid) dan sifat melawan hukum materil (matereile wederrechtelijkheid). Sifat melawan hukum formal terjadi karena memenuhi rumusan undang-undang (delik) tertulis, sifat melawan hukum formal merupakan syarat untuk dapat dipidananya perbuatan, jika ada alasan-alasan pembenar, maka alasan-alasan tersebut harus juga disebutkan secara tegas dalam undang-undang. Adapun sifat melawan hukum materil dalam hukum pidana Indonesia adalah yang terdapat dalam hukum adat dan hukum agama (delik adat dan delik agama), atau perbuatan tercela meskipun belum diatur dalam undang-undang, namun bertentangan dengan asas-asas hukum secara umum, sifat melawan hukum itu dapat dihapuskan berdasar ketentuan undang-undang maupun aturan tidak tertulis. Ajaran materil juga menyatakan, di samping memenuhi syarat-syarat formil, perbuatan itu juga harus benar-benar dirasakan oleh masyarakat sebagai perbuatan yang tidak patut atau tercela. Sulistia, T. (2014). Hukum Pidana. Jakarta: Raja Grafindo Persada, h. 6772.

393 |S A S I Vol. 27 No.3, Juli - September 2021 
Ketiga, unsur subjektif dari perbuatan tercela Presiden/Wakil Presiden adalah adanya kesalahan, yakni mengenai keadaan batin Presiden/Wakil Presiden sebelum atau pada saat melakukan pelanggaran sumpah/janji dalam keadaan sadar, sehat jasmani/rohani (tidak gila) dan tanpa paksaan, sehingga dapat diminta pertanggung jawaban; Keempat, semua perbuatan yang melanggar delik hukum Pidana adalah perbuatan tercela, dan sanksinya adalah pidana sesuai dengan KUHPidana, sehingga perbuatan tercela yang sudah diatur secara formal dalam KUHPidana bukanlah makna perbuatan tercela yang dimaksud dalam Pasal 7A UUD 1945, sebab sudah ditentukan limitatif perbuatan pidana yang dapat memberhentikan Presiden/Wakil Presiden dalam masa jabatannya, yakni: korupsi, penyuapan, dan tindak pidana berat lainnya. ${ }^{108}$

Terkait dengan hubungan kewajiban memenuhi sumpah/janji dan kesalahan Presiden/Wakil Presiden, Moeljatno menjelasakan bahwa seseorang (Presiden/Wakil Presiden) dapat dikatakan mempunyai kesalahan, jika perbuatan tersebut, dilihat dari segi masyarakat dapat dicela, yaitu: mengapa melakukan perbuatan tercela (tidak memenuhi sumpah/janji) yang merugikan masyarakat, padahal dia mampu dan seharusnya dia dapat, bahkan harus menghindar dari perbuatan tercela tersebut. Dengan demikian tentu saja perbuatan tercela itu sengaja dilakukannya, seseorang juga dapat dicela meskipun tidak sengaja (alpa) atau lalai terhadap kewajiban yang oleh masyarakat dipandang seharusnya dijalankan olehnya (Presiden/Wakil Presiden). ${ }^{109}$

Berdasar pendapat Moeljatno, maka dapat ditarik pengertian: Pertama, makna perbuatan tercela Presiden/Wakil Presiden adalah semua perbuatan yang memenuhi rumusan undangundang yang tertulis; Kedua, perbuatan yang dilakukan oleh Presiden/Wakil Presiden tersebut menurut masyarakat Indonesia dapat dicela baik menurut adat istiadat maupun agama serta merugikan masyarakat; ${ }^{110}$ Ketiga, ketika melakukan perbuatan tercela tersebut Presiden/Wakil Presiden mengerti dan sadar baik secara jasmani maupun rohani (psikologis) bahwa perbuatan itu merugikan masyarakat, namun dia tetap melakukannya, sehingga dia dicela oleh masyarakat meskipun tidak sengaja atau karena lalai (alpa) terhadap kewajibannya. ${ }^{111}$

108 Terkait dengan kesalahan (sehuld) sebagai perbuatan tercela yang dapat diminta pertanggungjawaban pidana, serta patut untuk mendapatkan hukuman dalam konsep hukum pidana, sebagai berikut: (1) Kesalahan adalah keseluruhan syarat yang memberikan dasar adanya pencelaan pribadi terhadap pelaku; (2) Kesalahan adalah terdapatnya keadaan psikologis tertentu pada seseorang yang melakukan perbuatan dan adanya hubungan antara keadaan tersebut dengan perbuatan yang dilakukannya itu, sehingga orang tersebut dapat dicela; (3) Kesalahan pada hakekatnya adalah tidak dihindarinya perbuatan melawan hukum sehingga mengakibatkan si pelaku dapat dicela dari akibatnya perbuatannya. Pendapat ini disampaikan oleh Metzger, Simon, Pompe dan Van Hamel. Ibid.

109 Ibid., h. 79-80.

110 Oleh sebab itulah Presiden/wakil Presiden sebelum memangku jabatannya harus bersumpa atau berjanji dengan sungguh-sungguh akan memenuhi kewajiban Presiden Republik Indonesia (Wakil Presiden Republik Indonesia) dengan sebaik-baiknya dan seadil-adilnya, memegang teguh Undang-Undang Dasar dan menjalankan segala undang-undang dan peraturannya dengan selurus-lurusnya serta berbakti kepada Nusa dan Bangsa, supaya tidak melakukan perbuatan-perbuatan yang merugikan masyarakat, karena semua keingginan masyarakat secara sudah terumuskan dalam kosntitusi (UUD 1945) dan serta dalam semua undang-undang dan peraturannya. Dengan pengertian ini juga, maka pelanggaran atau tidak dapat memenuhi sumpah atau janji adalah makna lain dari perbuatan tercela Presiden dan atau Wakil Presiden, sebab Presiden dan atau Wakil Presiden telah melakukan sumpah palsu. Lihat Pasal 9 UUD 1945. Lihat juga Pasal 6 UUD 1945 yang mengharuskan calon Presiden/calon Wakil Presiden harus seorang warga negara Indonesia sejak kelahirannya dan tidak pernah menerima kewarganegaraan lain karena kehendaknya sendiri, tidak pernah mengkhianati negara.

111 Argumentasi inilah yang mendasari UUD 1945 (konstitusi) mengharusan bagi calon Presiden/calon Wakil Presiden harus mampu secara rohani dan jasmani untuk melaksanakan tugas dan kewajiban sebagai Presiden/Wakil Presiden, sebab kesalahan (dalam arti perbuatan tercela) berkaitan erat dengan pertanggungjawaban hukum, misalnya orang gila (tidak sehat rohani dan jasmaninya), orang yang terpaksa atau di bawah pengaruh/ancaman orang lain tidak dapat diminta pertanggungjawaban hukum. Sebagai contoh: Presiden/Wakil Presiden yang di bawah ancaman atau todongan senjata, sehingga melakukan perbuatan yang dilarang atau bertentangan dengan kosntitusi (UUD 1945) dan/atau peraturan perundang-undangan lainnya, yang mengakibatkan Presiden/Wakil Presiden tidak dapat memenuhi kewajibannya dengan sebaik-baiknya dan seadiladilnya, tidak lagi memegang UUD 1945 dan menjalankan segala undang-undang serta peraturannya dengan selurus-lurusnya serta tidak mampu lagi berbakti kepada Nusa dan Bangsa, maka tidak dapat diminta

394 | S A S I Vol. 27 No.3, Juli - S e ptember 2021 
Pengertian perbuatan tercela sebagaimana yang dikemukakan di atas senada dengan Herman Mennheim yang mengatakan bahwa: "Penal Code is the most faithful mirror of civilization of a nation," jika dielaborasi jenis-jenis delik yang ada dalam KUHPidana berbagai negara, maka didapatkan adanya delik-delik yang dipandang netral, artinya semua negara memandang sama perbuatan tercela, seperti: pencurian, pembunuhan, pemerkosaan, penipuan, penganiayaan, pelanggaran sumpah/janji dan sejenisnya dapat dipidana. ${ }^{12}$ Namun, tidak selalu ukuran nilai perbuatan tercela itu masuk KUHPidana, kepentingan ketertiban umum atau konstitusi juga dapat dijadikan delik, contohnya penghinan terhadap pejabat negara, bendera, atau lambang negara dan seterusnya. ${ }^{13}$ Sebaliknya ada perbuatan tercela, tetapi tidak perlu masuk ke dalam KHUPidana, misalnya suka berhutang, suka berbohong, tidak amanah, ingkar janji (sumpah paslu), dan sejenisnya, sanksi dalam perbuatan tercela seperti ini lebih tetap diberikan dalam hukum hukum tata negara atau perdata. ${ }^{114}$

\section{Makna Perbuatan tercela Pada Pasal 7A UUD 1945 Dalam Konsep Hukum Pidana}

Dengan adanya batasan yuridis, suatu perbuatan tercela yang sudah memenuhi rumusan delik dalam undang-undang tidak serta merta dapat dinyatakan sebagai tindak pidana. Untuk dapat dinyatakan sebagai tindak pidana, perbuatan tercela (melawan hukum secara formal), harus juga bersifat melawan hukum secara materil, dengan kata lain ketiadaan sifat melawan hukum (absence of unlawfulness) mempunyai konsekuensi perbuatan pidana tersebut tidak dapat dipidana, sebab syarat pidana juga merupakan pernyataan tercela kepada diri si pelaku. ${ }^{115}$

Sehubungan dengan hal tersebut, maka alasan yang paling logika untuk menilai suatu perbuatan tercela adalah perbuatan yang melanggar norma-norma, baik dalam bentuk norma hukum, norma masyarakat, norma agama dan adat budaya, ${ }^{116}$ oleh sebab itu asas hukum pidana

pertanggungjawaban. Sebaliknya, Presiden/Wakil Presiden yang tidak berada dalam keadaan demikian, namun tetap melakukan perbuatan tercela, maka sudah layak dan pantas untuk dimakzulkan, sebab sehat rohani dan jasmani, serta dapat diminta pertanggungjawaban hukum. Ibid., h. 80.

112 Delik-delik seperti ini terdapat pada KUHPidana semua negara tanpa melihat ideology, budaya, adat, dan agama. Delik-delik baru sebagai akibat dari kemajuan teknologi, seperti delik computer, internet, media sosial elektronik, pembajakan udara, delik cyber, many laundering, penyadapan telepon, perekaman pembicaraan tanpa izin, delik lingkungan hidup, terorisme, narkotika, dan sejenisnya juga bersifat netral. Hamzah, A. (2008). Perbandingan Hukum Pidana Beberapa Negara. Edisi Ketiga. Cetakan Ketiga. Jakarta: Sinar Grafika, h. 6-8.

113 Pasal 207 KUHPidana berada di dalam Bab VIII yang berujudul Kejahatan terhadap Penguasa Umum. Bab ini dimulai dari Pasal 207 sampai dengan Pasal 241. Meski demikian beberapa pasal sudah dicabut, yaitu: Pasal 230 dan 241 Ayat (1). Delik-delik yang diatur dalam Bab ini diantaranya adalah delik penghinaan terhadap penguasa/badan umum, perbuatan yang mengancam kepada harkat dan martabat penguasa atau pejabat, termasuk juga delik-delik penyuapan, memaksa pejabat atau penguasa umum melakukan sesuatu atau tidak melakukan sesuatu yang bertentangan dengan jabatannya, melawan atau menghalangi pejabat yang sedang menjalankan tugas, tidak mau hadir dipanggil sebagai saksi atau ahli oleh pengadilan dan beberapa delik liannya. Delik yang diatur dalam Pasal 207 KUHPidana ini merupakan delik yang ditujukan kepada pejabat, dan jabatan atau penguasa umum sebagai delik formil, artinya delik ini sempurna sebagai delik ketika perbuatan yang terlarang tersebut dilakukan. Dalam kaitan dengan hal tersebut setidaknya ada 3 pasal yang bisa ditafsirkan sebagai delik materil, yaitu: Pasal 213 dan 214, yang berhubungan dengan delik yang melawan atau memaksa pejabat yang sedang menjalankan tugas yang menimbulkan luka. Demikian juga dengan Pasal 217 yaitu: perbuatan (perbuatan-perbuatan) yang menimbulkan kegaduhan di sidang pengadilan. Pasal ini telah diuji (judicial review) ke Mahkamah Konstitusi (MK), dalam pertimbangan Putusan No. 013-022/PUU-IV/2006, MK menyebutkan bahwa terkait pemberlakuan Pasal 207 KUHPidana, penuntutan hanya dilakukan atas dasar pengaduan dari penguasa. Jadi, apabila pemerintah yang dihina tersebut tidak mengadukan kasus penghinaan ini maka tidak dapat dipidana. Dengan demikian jelas bahwa sejak putusan MK ini maka rumusan delik Pasal 207 dirubah dari jenis delik biasa menjadi delik aduan. Sofian, A. (2019). Tafsir Delik Penghinaan Kepada Penguasa (Pasal 207 KUHP). https://businesslaw.binus.ac.id/2019/04/04/Tafsir-delik-penghinaan-kepada-penguasa-pasal-207-kuhp/, (Diakses Tanggal, 24 November 2020).

114 Hamzah, A. (2008). Op.Cit., h. 7.

115 Muladi, Arief, B. N. (1984). Teori-teori dan Kebijakan Pidana. Bandung: Alumni, h. 2-4.

116 Berkaitan dengan RUU KUHPidana yang sedang dibahas, hukum pidana selalu mengandung dua unsur pokok yaitu: (1) Adanya norma yang dianggap mengikat (baik itu bersifat larangan atau suruhan/verbods en gebodsbepalingen), dan (2) Adanya sanksi (straf, punishment) atau penghargaan (reward) yang mengikutinya. Ibid.

395 | S A S I Vol. 27 No.3, Juli - September 2021 
dalam konsep RUU KUHPidana adalah berlandaskan pada pokok pemikiran sistem hukum nasional yang berpangkal pada asas keseimbangan nilai-nilai dalam Pancasila (UUD 1945) dan asas keseimbangan tujuan pembangunan nasional, yaitu: keseimbangan antara "perlindungan masyarakat" (social defence) dan "kesejahteraan masyarakat " (social welfare). ${ }^{117}$

Secara teori, KUHPidana berisi tentang larangan perbuatan yang buruk, tentang nilainilai kesusilaan dan agama (das recht ist das ethische minimum) dari suatu masyarakat, karena perbuatan yang diatur merupakan perbuatan yang dianggap tercela dan asusila, karenanya harus dikenai sanksi sebagai bentuk tangung jawab. ${ }^{118}$ Pemberian sanksi atas kesalahannya ditujukan untuk melindungi masyarakat, ${ }^{119}$ adapun dalam kehidupan bermasyarakat dan bernegara, bertujuan untuk mendapatkan ketertiban, keamanan dan kesejahteraan sosial bagi masyarakat. ${ }^{120}$

Terkait dengan perbuatan tercela sebagai suatu kejahatan, dalam konsep hukum pidana ada dikenal dengan istilah mala per se atau mala in se, yang menganggap bahwa kesalahan tertentu merupakan kejahatan yang berkaitan dengan hati nurani dan dianggap tercela bukan karena peraturan perundang-undangan telah melarangnya, melainkan memang sudah dengan sendirinya salah. Sedangkan konsep mala in probohitia bertitik tolak dari pemikiran bahwa perbuatan dianggap tercela atau salah karena perundang-undangan telah melarangnya, sehingga disebut sebagai regulatory offenses. ${ }^{121}$

Oleh karenanya, antara perbuatan tercela yang dilarang atau strafbaar dan ancaman pidana atau strafmaat mempunyai hubungan sebab akibat (kausalitas). Jika dilihat dari hakekatnya, tindak pidana adalah perbuatan yang tercela (tercela karena dilarang oleh undangundang), sedangkan hukuman/pidana merupakan konkretisasi dari celaan. Bahkan larangan terhadap perbuatan yang termaktub dalam rumusan tindak pidana, timbul karena adanya ancaman penjatuhan pidana bagi yang melakukan perbuatan tercela. ${ }^{122}$ Ukuran untuk menilai perbuatan tercela tersebut adalah dengan adanya pelanggaran terhadap norma-norma atau kaedah-kaedah yang berakar pada nilai-nilai sosial-budaya, sebagai sistem tata kelakuan dan pedoman perbuatan masyarakat, yang dapat menyangkut norma keagamaan, kesusilaan dan hukum. Contohnya, tidak memenuhi sumpah/janji adalah suatu perbuatan tercela dalam

117 Cahyadi, E. (2007). Delik-Delik Keagamaan di Dalam RUU KUHP Indonesia. Cetakan Pertama. Jakarta: Kerjasama Aliansi Nasional Reformasi KUHP dan DRSP-USAID, h. LX-LXI.

118 Perbuatan tersebut merupakan kumpulan perbuatan dari begitu banyak perbuatan yang dinilai tercela dalam masyarakat. Selanjutnya pengaturan larangan perbuatan tercela yang merupakan delik, diatur juga dalam agama dan adat, yang memberikan larangan atau mencela perbuatan tersebut. Lihat mulai dari Pasal 104-488 KUHPidana (Buku II Kejahatan/misdrijven), Pasal 489-569 KUHPidana (Buku III Pelanggaran/overtredingen). Ismansyah., \& Ermawati B. (2012). Op. Cit, h. 27.

119 Berikutnya pengaruh aliran modern dalam hukum pidana, memperkaya hukum pidana dengan sanksi yang disebut dengan tindakan (measure, maatregel), secara dogmatis pemidanaan (penghukuman) adalah sebagai pengimbalan atau pembalasan terhadap kesalahan-kesalahan si pelaku. Jerman, Nederland dan Indonesia adalah negara yang KUHPidana-nya menggunkan konsep double track system ini, artinya dalam KUHPidana digunakan dua jenis sanksi tersebut. Baca lebih lanjut Ersan, P., \& Erliyana, A. (2018). Kualifikasi Hukum Pidana Khusus Terhadap Tindak Pidana Pemilu/Pilkada (Tinjauan Hukum Administrasi Negara). Pakuan Law Review, 4(1), h. 67.

120 Menurut Romli, suatu kejahatan sering timbul disebabkan oleh kekuasaan negara, yang membentuk perundang-undangan, sehingga "kekuasaan menjadi penyebab dari kejahatan." Atmasasmita, R. (2010). Teori dan Kapita Selekta Kriminologi. Bandung: Refika Aditama, h. 3.

121 Fitroh Rohcahyanto berpandangan, hal ini akibat dari KUHPidana tidak memandang delik kesusilaan sebagai perbuatan tercela dan sangat buruk, melainkan sebagai perlindungan terhadap korban, sehingga menyebabkan pengaturan delik kesusilaan dalam KUHPidana berbeda dengan pengaturan kejahatan kesusilaan dalam hukum pidana Adat, kejahatan kesusilaan menurut beberapa daerah hukum Adat yang dipengaruhi normanorma agama, meletakkan delik kesusilaan tidak hanya untuk melindungi korban, tapi juga merupakan perbuatan yang sangat tercela dan buruk, sehingga patut mendapat hukuman. Rohcahyanto, F. (2018). Memperdagangkan Pengaruh (trading in influence) Sebagai Tindak Pidana Korupsi. Disertasi, Program Doktor Ilmu Hukum Fakultas Hukum Universitas Airlangga, h. 120.

122 Waluyo, B. (2008). Pidana dan Pemidanaan. Edisi. 1. Cetakan. 3. Jakarta: Sinar Grafika, h. 1.

$$
396 \text { | S A S I Vol. } 27 \text { No.3, Juli - September } 2021
$$


pandangan masyarakat. ${ }^{123}$ Hal ini tentu saja senada dengan Soerjono Soekanto, yang menjelaskan bahwa kaedah hukum itu terhimpun dalam sistem hukum yang pada hakekatnya merupakan konkretisasi dari nilai-nilai sosial-budaya yang terwujud dan terbentuk dari kebudayaan suatu masyarakat. ${ }^{124}$

Terkait dengan nilai-nilai sosial-budaya, pengaturan delik kesusilaan sebagai perbuatan tercela dalam KUHPidana di Indonesia lebih menitikberatkan pada perlindungan terhadap korban tindakan asusila, berbanding terbalik dengan hukum Adat. ${ }^{125}$ Sedangkan delik agama dalam KHUPidana adalah mencakup perbuatan-perbuatan yang menurut hukum yang berlaku merupakan tindak pidana dan dilihat dari sudut pandang agama juga merupakan perbuatan tercela. ${ }^{126}$ Dasar yang digunakan untuk memasukkan delik agama dalam KUHPidana adalah Pancasila dan Pasal 29 UUD 1945, yang menegaskan negara berdasar Ketuhanan Yang Maha Esa. $^{127}$

Merujuk dari penjelasan-penjelasan di atas, maka makna perbuatan tercela Presiden/Wakil Presiden dalam konsep hukum pidana adalah semua perbuatan yang bertentangan dengan nilai-nilai sosial budaya bangsa, perbuatan yang tidak baik, tidak bermoral, serta apa yang tidak diperbolehkan/dilarang dan apa yang seharusnya dilakukan, sebagaimana yang terdapat dalam KUHPidana. ${ }^{128}$ Adapun nilai-nilai agama, sosial budaya bangsa, kaedahkaedah kesusilaan yang terdapat di KUHPidana itu sudah terhimpun dalam Pancasila yang kemudian dijabarkan oleh UUD 1945 sebagai norma-norma hukum yang disepakati bersama. Penyimpangan perilaku Presiden dan/atau Wakil Presiden terhadap UUD 1945, yang menyebabkan terganggunya ketertiban dan ketentreraman kehidupan manusia dalam berbangsa

123 Pengaturan tentang perzinahan dalam KUHPidana disebut dengan istilah "gendak," yaitu: suatu perbuatan yang dilakukan oleh suami yang memiliki istri dengan isteri yang memiliki suami dan berlaku sebaliknya, sebagai delik aduan.

124 Soekanto, S. (2015). Op.Cit., h. 43-44.

125 Sebagai contohnya dapat dilihat dari delik zina, dimana apabila yang melakukan kesusilaan tersebut adalah seorang laki-laki dan perempuan yang sudah sama-sama dewasa dan tidak terikat perkawinan, baik keduaduanya maupun salah satunya, maka hukum pidana tidak memandang sebagai kejahatan kesusilaan. Lihat buku Amriyanto. (2017). Menakar Nilai Agama dan Moral dalam Hukum Pidana Indonesia. Khairun Law Journal, 1 (1), h. 67-68.

126 Baca buku Jazuli, A. (2017). Op. Cit., h. 337. Contohnya: korupsi dan tidak memenuhi sumpah/janji adalah perbuatan tercela, baik dari pandangan negara, agama, maupun adat budaya Indonesia. Baca juga Nurhayati, R, dkk. (2013). Pemahaman Tentang Korupsi (Suatu Tinjauan Yuridis dan Sosiologis terhadap Konsep Korupsi di Indonesia), Jakarta: Laporan Penelitian Kerjasama Antar Perguruan Tinggi (Pekerti) Universitas Terbuka, h. 31.

127 Ketuhanan Yang Maha Esa sebagai titik sentral dari kehidupan kenegaraan, maka delik "godslastering" sebagai "blasphemy" menjadi prioritas dalam delik agama. Mudzakkir. (2010). Tindak Pidana Terhadap Agama Dalam Kitab Undang-Undang Pidana (KUHP) dan Undang-Undang Nomor 1/PNPS/1965 tentang Pencegahan Penyalahgunaan dan/atau Penodaan Agama (Kajian Terhadap Praktek Penegakan Hukum Dan Prospek Pengaturannya Dalam Hukum Positif Indonesia). Jakarta: Pusat Perencanaan Pembangunan Hukum Nasional Badan Pembinaan Hukum Nasional Kementerian Hukum Dan Hak Asasi Manusia, h. 9.

128 Sholehuddin, M. (2007). Sistem Sanksi Dalam Hukum Pidana: Ide Dasar Double Track System \& Implementasinya. Edisi. 1. Cetakan. 3. Jakarta: Raja Grafindo Persada, h. 55. Hukum pidana di Indonesia menganut asas legalitas, sesuai dengan Pasal 1 Ayat (1) KUHPidana, yang menegaskan bahwa "tiada suatu perbuatan dapat dipidana kecuali atas kekuatan aturan pidana dalam perundang-undangan yang telah ada sebelum perbuatan dilakukan.” Begitu juga dalam konsep RUU KUHPidana Tahun 2019, dalam Pasal 1 Ayat (1) juga menegaskan bahwa "tidak ada satu perbuatan pun yang dapat dikenai sanksi pidana dan/atau tindakan kecuali atas kekuatan peraturan pidana dalam peraturan perundang-undangan yang telah ada sebelum perbuatan dilakukan." Kemudian Pasal 2 Ayat (1), merumuskan pula, bahwa "ketentuan sebagaimana dimaksud dalam Pasal 1 ayat (1) tidak mengurangi berlakunya hukum yang hidup dalam masyarakat yang menentukan bahwa seseorang patut dipidana walaupun perbuatan tersebut tidak diatur dalam undang-undang itu; Ayat (2) Hukum yang hidup dalam masyarakat sebagaimana dimaksud pada Ayat (1) berlaku dalam tempat itu hidup dan sepanjang tidak diatur dalam Undang-Undang ini dan sesuai dengan nilai-nilai yang terkandung dalam Pancasila, Undang-Undang Dasar Negara Republik Indonesia Tahun 1945, hak asasi manusia, dan asas hukum umum yang diakui oleh masyarakat beradab. Dengan memperhatikan konsepsi asas legalitas RUU KUHPidana tersebut, maka menurut Wijaksana bertolak pada keseimbangan antara asas legalitas formal dan asas legalitas materil. Baca juga Wijaksana, M. M. S. (2020). Op. Cit., h. 5.

$$
397 \text { | S A S I Vol. } 27 \text { No.3, Juli - September } 2021
$$


dan bernegara adalah perbuatan tercela. ${ }^{129}$

Senapas dengan hal di atas, E.Y, Kanter dan S.R Sianturi menjelaskan bahwa tujuan hukum pidana pada umumnya adalah untuk melindungi kepentingan orang perseorangan (individu) atau hak-hak asasi manusia dan melindungi kepentingan-kepentingan masyarakat serta negara dari tindakan penguasa yang sewenang-wenang. ${ }^{130}$ Sebab itu, ketika seseorang (Presiden/Wakil Presiden) melakukan suatu perbuatan atau kebijakan haruslah terlebih dahulu mempertimbangkan apakah yang dilakukan sesuai dengan hukum dan moral kemanusiaan atau tidak. ${ }^{131}$ Pendapat senada disampaikan E.Ph. Sutorious, dengan mengatakan bahwa perbuatan tercela (sebagai kesalahan) adalah melakukan sesuatu yang seharusnya tidak dilakukan, dan tidak melakukan sesuatu yang seharusnya dilakukan. ${ }^{132}$

Selanjutnya secara formil perbuatan tercela Presiden/Wakil Presiden adalah disebabkan karena UUD 1945 melarang atau memerintahkan perbuatan tersebut yang disertai dengan ancaman sanksi. Adapun perbuatan tercela secara materil adalah karena perbuatan tersebut bertentangan atau tidak sesuai dengan nilai-nilai keberadaban masyarakat dan sanksi yang diberikan bukanlah sanksi pidana, tetapi sanksi yang terdapat dalam kaidah-kaidah UUD 1945, hal yang demikian adalah sesuai dengan Pancasila utamanya asas kemanusian yang adil dan beradab yang merupakan sendi dalam kehidupan berbangsa dan bernegara. ${ }^{133}$

Beranjak dari pemaparan yang telah disampaikan, maka didapat pengertian, sebagai berikut: Pertama, bahwa semua perbuatan yang melanggar delik hukum pidana adalah perbuatan tercela, dan sanksinya adalah pidana sesuai dengan KUHPidana, sehingga perbuatan tercela yang sudah diatur secara formal dalam KUHPidana bukanlah makna perbuatan tercela yang dimaksud dalam Pasal 7A UUD 1945, sebab sudah ditentukan limitatif perbuatan pidana yang dapat memberhentikan Presiden/Wakil Presiden dalam masa jabatannya, yakni: korupsi, penyuapan, dan tindak pidana berat lainnya; Kedua, perbuatan tercela Presiden/Wakil Presiden sebagaimana yang termaktub dalam Pasal 7A UUD 1945 adalah perbuatan pelanggaran terhadap UUD 1945 sebagai rujukan kaedah hukum (hukum pidana) yang disepakati bersama, disamping itu konstruksi perbuatan tercela dalam Pasal 7A UUD 1945 adalah campuran antara perbuatan tercela sebagai pelanggaran hukum dengan moral/etika, dengan demikian UUD 1945 adalah sebagai sumber rule of ethic bagi Presiden/Wakil Presiden. ${ }^{134}$

129 Supanto. (2004). Pelecehan Seksual Sebagai Kekerasan Gender: Antisipasi Hukum Pidana. Mimbar: Jurnal Sosial dan Pembangunan, 20(3), 288-310. h. 296.

130 Istiqamah, D. T. (2018). Analisis Nilai Keadilan Restoratif Pada Penerapan Hukum Adat Di Indonesia. Veritas et Justitia, 4(1), 201-226, h. 202.

131 Baca lebih lengkap Maramis, F. (2016). Op.Cit., h. 165. Dalam konsep hukum pidana juga ada dikenal dengan tindak pidana khusus, yang berarti bahwa perlakuan terhadap subjek hukum; hukum acara, acaman dan pengaturannya tergolong khusus, misalnya korupsi dan narkotika. Kejahatan mengenai perilaku tidak melaksanakan amanah serta tidak memenuhi kewajiban dan hak-hak negara (oleh Presiden/Wakil Presiden, misalnya); kejahatan terhadap ketertiban umum adalah juga mempunyai nilai kekhususan, meskipun sebahagian kejahatan-kejahatan tersebut sudah masuk dalm KUHPidana. Baca juga Siahaan, M. 2016. Pembaruan Hukum Pidana Indonesia. Jakarta: Gramedia, h. 10.

132 Kesalahan memandang hubungan antara perbuatan tercela dan pelakunya, artinya perbuatan tercela tersebut sesungguhnya merupakan perbuatannya. Amrani, H, Ali, M. (2015). Sistem Pertangungjawaban Pidana: Perkembangan dan Penerapan. Edisi. 1. Cetakan. 1. Jakarta: Raja Grafindo Persada, h. 24.

133 Farid, Z. A. (2007). Hukum Pidana 1. Edisi. 1. Cetakan. 2. Jakarta: Sinar Grafika, h. 242. Adapun Barda Nawawi Arif, mengemukakan bahwa pertanggungjawaban tindak pidana dititikberatkan kepada adanya perbuatan yang tercela secara objektif maupun tercela secara subjektf. Makna pencelaan secara objektif, ukurannya adalah adanya norma larangan maupun norma kaharusan dalam UU, perbuatan, kegiatan atau aktivitas memang patut dicela. Pencelaan secara subjektif, diarahkan kepada pelakunya bahwa dia patut di pidana. Asas yang mendasari pertanggungjawaban pidana merupakan asas kesalahan geen straf zonder schuld atau tiada pidana tanpa kesalahan. Arief, B. N. (2010). Bunga Rampai Kebijakan Hukum Pidana: (Perkembangan Penyusunan Konsep KUHP Baru), Edisi Pertama. Cetakan ke-2. Jakarta: Kencana, h. 89-95.

134 Said, H. M. (2021). Menggagas Peradilan Etik Penyelenggara Negara Di Indonesia. SASI, 27(1), 24-37. h. 33 .

398 |S A S I Vol. 27 No.3, Juli - September 2021 
Terkait dengan tindak pidana berat lainnya, MK telah mendefeniskan frasa tersebut, seperti terdapat dalam Pasal 10 Ayat (3) point (c) UU No. 24 Tahun 2003 tentang MK, yang menjelaskan bahwa: tindak pidana berat lainnya adalah tindak pidana yang diancam dengan pidana penjara 5 (lima) tahun atau lebih. Adapun tindak pidana yang diancam penjara 5 tahun atau lebih dalam KUHPidana dan tergolong khusus diantaranya: (1) Pembunuhan (diancam pidana 15 tahun), perampasan kemerdekaan (diancam pidana 8 tahun); (2) Kejahatan penerbangan yang bervariasi paling ringan 6 (enam) tahun dan paling berat diancam dengan pidana penjara 15 (lima belas) tahun; (3) Tindak pidana teroriseme diancam dengan pidana mati; (4) Dalam UU Informasi dan Transaksi Elektronik, ${ }^{135}$ tindak pidana melanggar kesusilaan diperberat pidananya selama 6 (enam) tahun; (4) Tindak pidana kekerasan dalam rumah tangga yang diancam dengan pidana penjara menjadi 10 (sepuluh) tahun penjara; (5) Tindak pidana korupsi, perbuatan memperkaya diri sendiri, orang lain atau korporasi yang dapat merugikan keuangan negara" yang semula diancam dengan pidana penjara 20 (dua puluh) tahun, diperberat menjadi jenis acaman pidana sampai pidana mati. ${ }^{136}$

\section{PE N T U P}

Dari pembahasan di atas dapat disimpulkan, sebagai berikut: Pertama, semua perbuatan yang bertentangan dengan KUHPidana adalah perbuatan tercela bagi Presiden/Wakil Presiden; Kedua, nilai-nilai agama, sosial budaya bangsa Indoneisa, serta kaedah-kaedah kesusilaan dalam KUHPidana sudah terhimpun dalam Pancasila dan UUD 1945, oleh karenanya penyimpangan perilaku Presiden/Wakil Presiden terhadap UUD 1945 adalah perbuatan tercela; Ketiga, semua perbuatan tercela Presiden/Wakil Presiden yang melanggar delik hukum pidana mendapatkan sanksi pidana sesuai dengan KUHPidana, sehingga perbuatan tercela yang sudah diatur secara formal dalam KUHPidana bukanlah makna perbuatan tercela yang dimaksud dalam Pasal 7A UUD 1945, sebab sudah ditentukan limitatif perbuatan pidana yang dapat memakzulkan Presiden/Wakil Presiden, yakni: korupsi, penyuapan, dan tindak pidana berat lainnya; Keempat, perbuatan tercela Presiden/Wakil Presiden dalam Pasal 7A UUD 1945 adalah perbuatan pelanggaran terhadap UUD 1945 sebagai rujukan kaedah hukum pidana yang disepakati bersama.

\section{DAFTAR PUSTAKA}

\section{Jurnal}

[1] Amriyanto, A. (2017). Menakar Nilai Agama dan Moral dalam Hukum Pidana Indonesia. Khairun Law Journal, 1(1), 62-72.

[2] Ersan, P., \& Erliyana, A. (2018). Kualifikasi Hukum Pidana Khusus Terhadap Tindak Pidana Pemilu/Pilkada (Tinjauan Hukum Administrasi Negara). Pakuan Law Review, 4(1).

[3] Huda, C. (2011). Pola Pemberatan Pidana dalam Hukum Pidana Khusus. Jurnal Hukum IUS QUIA IUSTUM, 18(4), 508-524.

[4] Istiqamah, D. T. (2018). Analisis Nilai Keadilan Restoratif Pada Penerapan Hukum Adat Di Indonesia. Veritas et Justitia, 4(1), 201-226.

[5] Ismansyah \& Ermawati, B. (2012). Permasalahan Delik Zina Yang Terdapat Dalam Kitab Undang-Undang Hukum Pidana (KUHP). Jurnal Delicti: Jurnal Hukum Pidana dan Kriminologi, $I X(1)$, h. 27.

[6] Iksan, M. (2017). Asas Legalitas Dalam Hukum Pidana: Studi Komparatif Asas Legalitas Hukum Pidana Indonesia Dan Hukum Pidana Islam (Jinayah). Jurnal Serambi Hukum, $11(01)$.

[7] Jafar, W. A. (2016). Analisis Asas Hukum Pidana Islam Dan Asas Hukum Pidana Di

135 Undang-Undang No. 11 Tahun 2008 tentang Informasi dan Transaksi Elektronik.

136 Ancaman pidana mati juga diberikan bagi pelaku tindak pidana Norkotika. Lihat juga Taufik, I. (2018). Kendala Dalam Pelaksanaan Pembelian Terselubung (Undercover Buy) Dalam Mengungkap Tindak Pidana Narkotika Oleh Penyidik Polri. Sasi, 23(2), 118-128, h. 119. 
Indonesia. Al-Istinbath: Jurnal Hukum Islam, 1(1), 25-44.

[8] Jazuli, A. (2017). Penyelesaian Konflik Penodaan Agama Dalam Perspektif Hukum Pidana Di Indonesia. Jurnal Penelitian Hukum De Jure, 17(3), 329-350

[9] Nurdin, F. S. (2016). Rekonstruksi Asas Legalitas Dalam Hukum Pidana Berdasarkan Prinsip Keadilan, Jurnal Refleksi Hukum, 1 (1).

[10] Supanto, S. (2004). Pelecehan Seksual Sebagai Kekerasan Gender: Antisipasi Hukum Pidana. Mimbar: Jurnal Sosial dan Pembangunan, 20(3), 288-310.

[11] Sudharmawatiningsih. (2007). Sifat Melawan Hukum Materil Dalam Tindak Pidana Korupsi (Respon Terhadap Putusan Mahkamah Konstitusi). Jurnal Hukum Dan Dinamika Masyarakat, 5(1).

[12] Supusesa, R. (2012). Eksistensi Hukum Delik Adat Dalam Perspektif Pembaharuan Hukum Pidana Di Maluku Tengah. Jurnal Mimbar Hukum, 24(1), 41-54.

[13] Said, H. M. (2021). Menggagas Peradilan Etik Penyelenggara Negara Di Indonesia. SASI, 27(1), 24-37.

[14] Taufik, I. (2018). Kendala Dalam Pelaksanaan Pembelian Terselubung (Undercover Buy) Dalam Mengungkap Tindak Pidana Narkotika Oleh Penyidik Polri. Sasi, 23(2), 118-128.

[15] Wijaksana, M. M. S. (2020). Perkembangan Formulasi Asas Legalitas Dalam Sistem Pemidanaan Di Indonesia (Studi Komparatif Antara KUHP/WVS \& RUU KUHP 2019). Jurnal RechtsVinding.

\section{Buku}

[16] Atmasasmita, R. (2010). Teori dan Kapita Selekta Kriminologi. Bandung: Refika Aditama. [17]Arief, B. N. (2010). Bunga Rampai Kebijakan Hukum Pidana: (Perkembangan Penyusunan Konsep KUHP Baru), Edisi Pertama. Cetakan ke-2. Jakarta: Kencana.

[18] Anam, K, M. (2015). Teori Hukum Murni Dasar-Dasar Ilmu Hukum Normatif. Cetakan 7. Bandung: Nusa Media.

[19] Amrani, H, Ali, M. (2015). Sistem Pertangungjawaban Pidana: Perkembangan dan Penerapan. Edisi. 1. Cetakan. 1. Jakarta: Raja Grafindo Persada.

[20] Atmadja, I. G. D., Budiartha, I. P. N. (2018). Teori-Teori Hukum. Malang: Setara Press.

[21] Badan Pembinaan Hukum Nasional. (2015). Naskah Akademik Rancangan UndangUndang Tentang Kitab Undang-Undang Hukum Pidana (KUHP). Jakarta: Kementerian Hukum dan Hak Asasi Manusia Republik Indonesia.

[22] Cahyadi, E. (2007). Delik-Delik Keagamaan di Dalam RUU KUHP Indonesia. Cetakan Pertama. Jakarta: Kerjasama Aliansi Nasional Reformasi KUHP dan DRSP-USAID.

[23] Chazawi, A. (2011). Pelajaran Pidana Bagian 1. Edisi ke-1. Cetakan ke-6. Jakarta: Raja Grafindo Persada.

[24] Farid, Z. A. (2007). Hukum Pidana 1. Edisi. 1. Cetakan. 2. Jakarta: Sinar Grafika.

[25] Hamzah A. (2008). Terminologi Hukum Pidana, Edisi Pertama. Cetakan Pertama. Jakarta: Sinar Grafika.

[26] Hamzah, A. (2008). Asas-Asas Hukum Pidana. Edisi Revisi. Jakarta: Rineka Cipta.

[27] Hamzah, A. (2008). Perbandingan Hukum Pidana Beberapa Negara. Edisi Ketiga. Cetakan Ketiga. Jakarta: Sinar Grafika.

[28] Hidayati, F. R. (2019). Memperkuat Peradaban Hukum dan Ketatanegaraan Indonesia. Cetakan Pertama. Jakarta: Sekretariat Jenderal Komisi Yudisial Republik Indonesia.

[29] Imran., \& Hidayati, F. R. (2019). Memperkuat Peradaban Hukum dan Ketatanegaraan Indonesia. Cetakan Pertama. Jakarta: Sekretariat Jenderal Komisi Yudisial Republik Indonesia.

[30] Kusumaatmadja, M. (2006). Konsep-Konsep Hukum Dalam Pembangunan. Cetakan ke-2. Bandung: Alumni.

[31] Marpaung, L. (1992). Proses Penanganan Perkara Pidana. Jakarta: Sinar Grafika.

[32] Moeljatno. (2002). Asas-Asas Hukum Pidana. Cetakan ke-tujuh. Jakarta: Rineka Cipta.

[33] Mudzakkir. (2010). Tindak Pidana Terhadap Agama Dalam Kitab Undang-Undang Pidana 400 |S A S I Vol. 27 No.3, Juli - September 2021 
(KUHP) dan Undang-Undang Nomor 1/PNPS/1965 tentang Pencegahan Penyalahgunaan dan/atau Penodaan Agama (Kajian Terhadap Praktek Penegakan Hukum Dan Prospek Pengaturannya Dalam Hukum Positif Indonesia). Jakarta: Pusat Perencanaan Pembangunan Hukum Nasional Badan Pembinaan Hukum Nasional Kementerian Hukum Dan Hak Asasi Manusia.

[34] Maroni. (2015). Pengantar Hukum Pidana Administrasi. Bandar Lampung: Anugrah Utama Raharja.

[35] Maramis, F. (2016). Hukum Pidana Umum dan Tertulis Indonesia. Edisi ke-1. Cetakan Ke3. Depok: Raja Grafindo Persada.

[36] Mertha I. K, dkk. (2016). Buku Ajar Hukum Pidana, Denpasar: Fakultas Hukum Universitas Udayana.

[37] Pohan, A, dkk. (2012). Hukum Pidana Dalam Perspektif. Edisi Pertama. Denpasar: Pustaka Larasan.

[38] Remmelink, J. (2003). Hukum Pidana: Komentar Atas Pasal-pasal Terpenting dari Kitab Undang-Undang Hukum Pidana Belanda dan Padanannya dalam Kitab Undang-undang Hukum Pidana Indonesia. Jakarta: Gramedia.

[39] Soekanto, S. (2004). Pokok-Pokok Sosiologi Hukum. Jakarta: Raja Grafindo Persada.

[40] Soekanto, S., Mamudji, S. (2006). Penelitian Hukum Normatif Suatu Tinjauan Singkat. Jakarta: Rajawali.

[41] Sholehuddin, M. (2007). Sistem Sanksi Dalam Hukum Pidana: Ide Dasar Double Track System \& Implementasinya. Edisi. 1. Cetakan. 3. Jakarta: Raja Grafindo Persada.

[42] Sudirman, A. (2009). Eksistensi Hukum Dan Hukum Pidana Dalam Dinamika Sosial Suatu Kajian Teori Dan Praktik Di Indonesia. Semarang: BP UNDIP.

[43] Sunggono, B. (2011). Metodologi Penelitian Hukum. Jakarta: Rajawali.

[44] Sulistia, T. (2014). Hukum Pidana. Jakarta: Raja Grafindo Persada.

[45] Siahaan, M. 2016. Pembaruan Hukum Pidana Indonesia. Jakarta: Gramedia.

[46] Sofyan, A., \& Azisa, N. (2016). Hukum Pidana. Cetakan Kesatu. Jakarta: Pustaka Pena Press.

[47] Suhartoyo. (2019). Argumen Pembalikan Beban Pembuktian Sebagai Metode Prioritas dalam Pemberantasan Tindak Pidana Korupsi dan Tindak Pidana Pencucian Uang. Depok: Raja Grafindo Persada.

[48] Waluyo, B. (2008). Pidana dan Pemidanaan. Edisi. 1. Cetakan. 3. Jakarta: Sinar Grafika.

\section{Online/World Wide Web, Disertasi dll}

[49] Fachri. (2019). Hakikat Putusan Mahkamah Konstitusi atas Pendapat Dewan Perwakilan Rakyat Mengenai Dugaan Pelanggaran Oleh Presiden dan/atau Wakil Presiden Menurut Undang-undang Dasar Negara Republik Indonesia Tahun 1945. Disertasi, Universitas Muslim Indonesia.

[50] Hufron. (2012). Pemberhentian Presiden dan/atau Wakil Presiden Menurut UndangUndang Dasar Negara Republik Indonesia Tahun 1945. Disertasi, Universitas Brawijaya.

[51] Nurhayati, R, dkk. (2013). Pemahaman Tentang Korupsi (Suatu Tinjauan Yuridis dan Sosiologis terhadap Konsep Korupsi di Indonesia), Jakarta: Laporan Penelitian Kerjasama Antar Perguruan Tinggi (Pekerti) Universitas Terbuka.

[52] Pebrihariati, S, R. (2013). Pemberhentian Presiden/Wakil Presiden dalam sistem ketatanegaraan di Indonesia. Disertasi, Universitas Airlangga.

[53] Rohcahyanto, F. (2018). Memperdagangkan Pengaruh (trading in influence) Sebagai Tindak Pidana Korupsi. Disertasi, Universitas Airlangga.

[54] Sofian, A. (2019). Tafsir Delik Penghinaan Kepada Penguasa (Pasal 207 KUHP). https://business-law.binus.ac.id/2019/04/04/Tafsir-delik-penghinaan-kepada-penguasapasal-207-kuhp/.

[55]Zoelva, H. (2010). Pemakzulan Presiden di Indonesia. Disertasi, Universitas Padjajaran. 